\title{
ansa-Metallocenes Bearing 4-( $N$-Azolyl)-2-methylindenyl and Related Ligands: Development of Highly Isoselective Catalyst for Propene Polymerization at Higher Temperatures
}

Vyatcheslav V. Izmer, ${ }^{\dagger}$ Artem Y. Lebedev, ${ }^{\dagger}$ Dmitry S. Kononovich, ${ }^{\dagger}$ Ilya S. Borisov, ${ }^{\dagger}$

Pavel S. Kulyabin, ${ }^{\dagger}$ Georgy P. Goryunov, ${ }^{\dagger}$ Dmitry V. Uborsky,${ }^{\dagger}$ Jo Ann M. Canich, ${ }^{\ddagger}$ and

Alexander Z. Voskoboynikov*,†

${ }^{\dagger}$ Department of Chemistry, Lomonosov Moscow State University, Leninskie Gory 1/3, Moscow 119991, Russia

‡Baytown Technology and Engineering Complex, ExxonMobil Chemical Company, 5200 Bayway Drive, Baytown, Texas 77520, USA

\section{Supporting Information}

\section{Table of contents}

Additional attempted synthetic chemistry

Synthesis

Details of computational studies.

Small scale propylene polymerization experiments

High pressure propylene polymerization experiments $\mathrm{S} 15$

X-ray crystallography data

References 


\section{Additional synthetic attempts}

In the presence of $\mathrm{Pd}\left(\mathrm{PtBu}_{3}\right)_{2}$ and $\mathrm{tBuOLi}$ in toluene, 7-chloro-2-methylindene and indole gave 2 in $98 \%$ yield (HPLC) after $48 \mathrm{~h}$ at reflux:

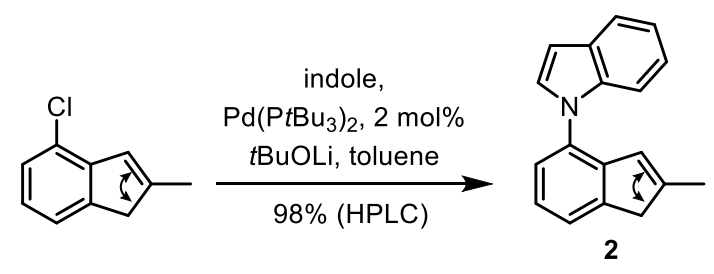

Carbazolyl substituted indene 7 can also be synthesized via methoxyindane route. In this way, 9(1-methoxy-2-methyl-2,3-dihydro-1H-inden-4-yl)carbazole is obtained by reaction between 4-bromo-1methoxy-2-methylindane and carbazolyllithium in the presence of $\mathrm{Pd}(\mathrm{OAc})_{2} / \mathrm{JohnPhos}$ in $74 \%$ yield. At the next stage, the amination product was converted into the desired indene 7 (93\% yield) by treatment with $\mathrm{TsOH}$ :

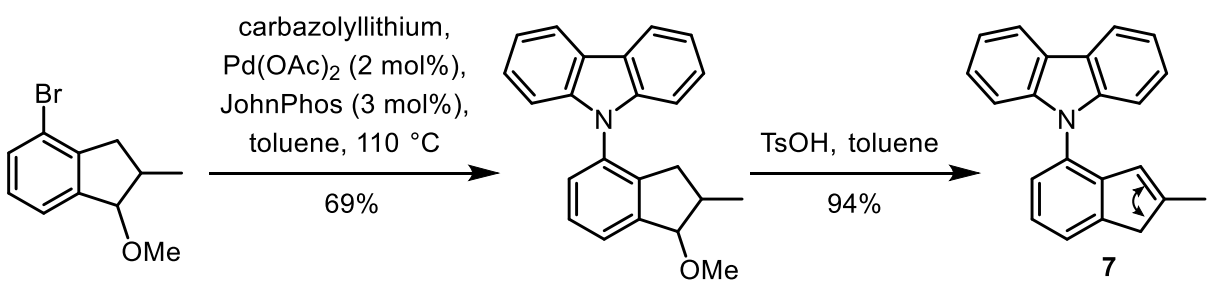

In principle, the dibenzophospholyl substituted indene $\mathbf{8}$ can be obtained by Pd-catalyzed cross-coupling reaction of 4-bromo-1-methoxy-2-methylindane with dibenzophosphole [1] or 5trimethylsilyldibenzophosphole [2] followed by acid-catalyzed elimination of $\mathrm{MeOH}$ from the product. However, preparation of dibenzophospholyl substituted methoxyindane using these catalytic methods may be accompanied by side substitution of the phosphine ligand(s) at palladium by phosphorouscontaining substrate and/or products resulting in (partial) catalyst deactivation. This may be one of the reasons of low yields in both cases (24 and 33\%, respectively). An alternative synthetic method based on nucleophilic substitution at phosphorous in 5-chlorodibenzophosphole by organolithium reagent obtained from 4-bromo-1-methoxy-2-methylindane and nBuLi in THF gave the same product in better yield $(50 \%)$. The following elimination of $\mathrm{MeOH}$ from the dibenzophospholyl substituted methoxyindane also resulted in low yield of indene 8, thus, the overall yield of $\mathbf{8}$ from 4-bromo-1-methoxy-2methylindane was found to be $8-17 \%$ making these approaches unpractical:

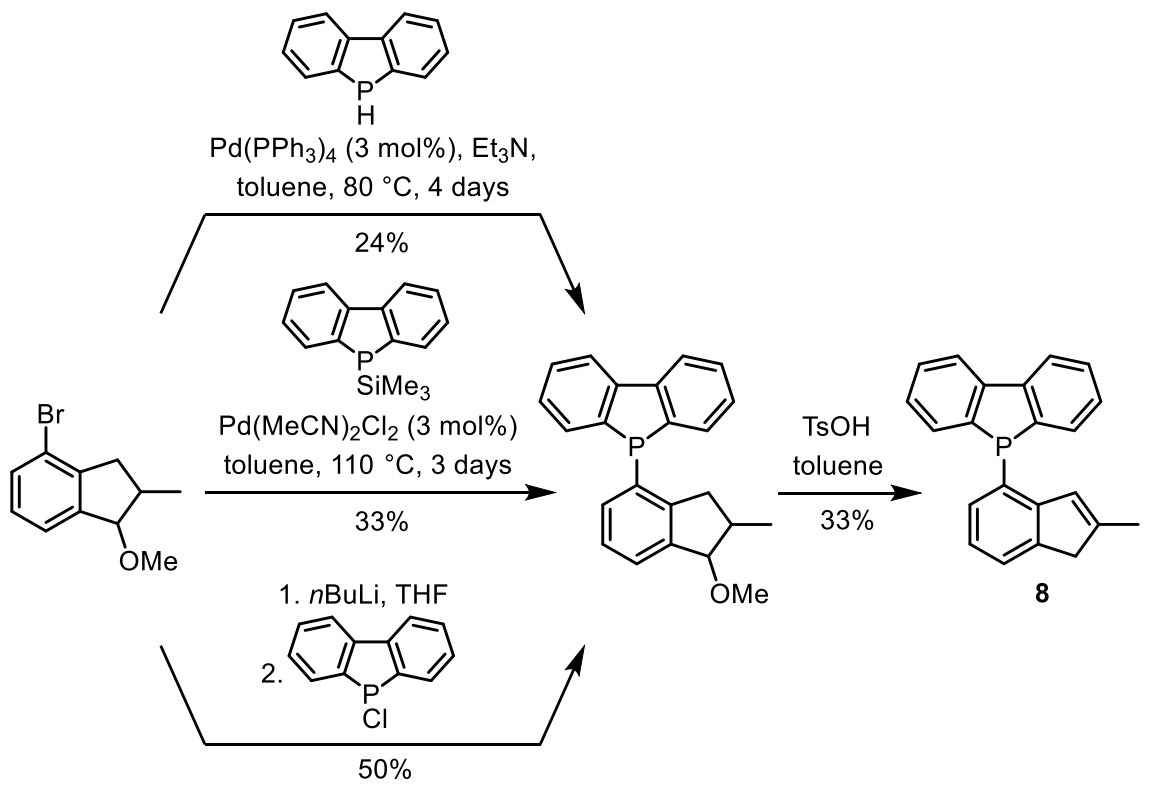




\section{Synthesis}

General Details. All manipulations with compounds, which are sensitive to moisture and air, were performed either in an atmosphere of argon using a standard Schlenk technique or in a controlled atmosphere glove box (VAC). Starting compounds 1 [3], and 5-chlorodibenzophosphole [4] were synthesized as previously described. Analytical and preparative liquid chromatography was performed using a Waters Delta 600 HPLC system including a 996 Photodiode Array Detector, analytical Symmetry C18 (Waters, $60 \AA, 5 \mu \mathrm{m}, 4.6 \times 250 \mathrm{~mm}$ ) and preparative Nova-Pack C18 (Waters, $60 \AA, 6 \mu \mathrm{m}, 3.9$ and $19 \times 300 \mathrm{~mm}$ ) columns in a methanol-water mobile phase. For analytical runs, calculations of yields of the products were performed under the assumption that extinction coefficients of isomeric indenes and diastereomeric methoxyindanes are equal. ${ }^{1} \mathrm{H}$ and ${ }^{13} \mathrm{C}$ NMR spectra were recorded with Bruker DPX-300 or Avance-400 spectrometers for $1-10 \%$ solutions in deuterated solvents. Chemical shifts for ${ }^{1} \mathrm{H}$ and ${ }^{13} \mathrm{C}$ are reported relatively to TMS and referenced to the residual ${ }^{1} \mathrm{H}$ or ${ }^{13} \mathrm{C}$ resonances of the deuterated solvents. C, H microanalyses were done using a Carlo Erba 1106 analyzer.

\section{Syntheses of indenes 2, 3, 6-8, 18-20 and bridged ligands 9-12}

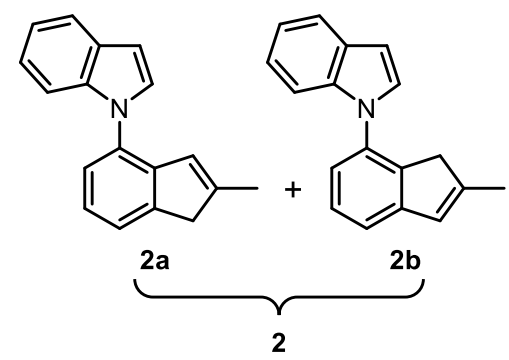

A mixture of 1-(2-methyl-1H-inden-4-yl)indole and 1-(2-methyl-1H-inden-7-yl)indole (2). A solution of $6.44 \mathrm{~g}(55.0 \mathrm{mmol})$ of $1 \mathrm{H}$-indole in $100 \mathrm{ml}$ of toluene was metallated by $20.0 \mathrm{ml}$ of $2.5 \mathrm{M}{ }^{\mathrm{n}} \mathrm{BuLi}(50 \mathrm{mmol})$ in hexanes by vigorous stirring at $0{ }^{\circ} \mathrm{C}$. The resulting mixture was warmed to room temperature and stirred for $15 \mathrm{~min}$; then, hexanes were distilled off in vacuum. To the residue, a solution of $9.41 \mathrm{~g} \mathrm{(45.0}$ $\mathrm{mmol})$ of $1 \mathrm{in} 60 \mathrm{ml}$ of toluene was added; then, $225 \mathrm{mg}(1.0 \mathrm{mmol})$ of $\mathrm{Pd}(\mathrm{OAc})_{2}$ and $448 \mathrm{mg}(1.5 \mathrm{mmol})$ of 2-[di(tert-butyl)phosphino]-1,1'-biphenyl were added. The resulting mixture was refluxed for $1 \mathrm{~h}$ and then cooled to ambient temperature. The solution was decanted, and the precipitate was additionally washed by $100 \mathrm{ml}$ of methyl-tert-butyl ether. The combined extract was evaporated using rotary evaporator. The crude product was dissolved in $100 \mathrm{ml}$ of hexanes. This solution was passed through short column with Silica Gel $60(40-63 \mu \mathrm{m}, \mathrm{d} 60 \mathrm{~mm}, \mathrm{I} 150 \mathrm{~mm}$; eluent: hexanes/dichloromethane = 2/1, vol). Vacuum distillation of the crude product gave yellowish oil, b.p. $122-125^{\circ} \mathrm{C} / 0.5 \mathrm{~mm} \mathrm{Hg}$. Yield 9.33 $\mathrm{g}(85 \%)$ of a ca. 1 to 1 mixture of 1 -(2-methyl-1H-inden-4-yl)indole (2a) and 1-(2-methyl-1H-inden-7yl)indole (2b). This oil crystallizes slowly at room temperature. Anal. calc. for $\mathrm{C}_{18} \mathrm{H}_{15} \mathrm{~N}: \mathrm{C}, 88.13 ; \mathrm{H}, 6.16$. Found: $\mathrm{C}$, 88.18; $\mathrm{H}, 6.13 .{ }^{1} \mathrm{H}$ NMR $\left(\mathrm{CDCl}_{3}\right): \delta 7.68(\mathrm{~m}, 2 \mathrm{H}$ in $2 \mathbf{2 a}$ and $2 \mathbf{b}), 7.10-7.37$ (m, 14H in 2a 2b), $6.66(\mathrm{~m}, 2 \mathrm{H}$ in $\mathbf{2 a}$ and $\mathbf{2 b}), 6.51(\mathrm{~m}, 1 \mathrm{H}$ in $\mathbf{2 a}), 6.28(\mathrm{~m}, 1 \mathrm{H}$ in $\mathbf{2 b}), 3.38(\mathrm{~m}, 2 \mathrm{H}$ in $\mathbf{2 a}), 3.15(\mathrm{~m}, 2 \mathrm{H}$ in $\mathbf{2 b})$, 2.07 (m, 3H 2-Me in 2a or 2b), 2.05 (m, 3H 2-Me in $\mathbf{2 b}$ or $\mathbf{2 a}) \cdot{ }^{13} \mathrm{C}\left\{{ }^{1} \mathrm{H}\right\}$ NMR $\left(\mathrm{CDCl}_{3}\right): \delta 148.0,147.2$, $146.8,145.2$, 141.7, 138.9, 136.6, 136.2, 134.8, 131.0, 128.7, 128.63, 128.56, 128.0, 127.7, 127.0, 124.6, 124.4, 123.9, 122.3, 121.92, 121.89, 121.7, 121.0, 120.8, 119.94, 119.88, 119.1, 110.9, 110.7, 102.7, 43.1, 41.4, 16.8, 16.6. 


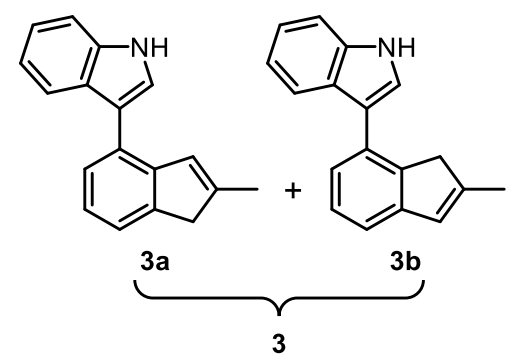

A mixture of 3-(2-methyl-1H-inden-4-yl)-1H-indole and 3-(2-methyl-1H-inden-7-yl)-1H-indole (3). To a solution of $117 \mathrm{mg}(1.0 \mathrm{mmol})$ of $1 H$-indole in $3 \mathrm{ml}$ of toluene, $0.4 \mathrm{ml}$ of $2.5 \mathrm{M}{ }^{\mathrm{n}} \mathrm{BuLi}(1.0 \mathrm{mmol})$ in hexanes was added at ambient temperature. The resulting mixture was stirred for $24 \mathrm{~h}$, and then $209 \mathrm{mg}$ $(1.0 \mathrm{mmol})$ of 1 and $10.2 \mathrm{mg}(0.02 \mathrm{mmol})$ of $\mathrm{Pd}\left(\mathrm{P}^{t} \mathrm{Bu}_{3}\right)_{2}$ were added. This mixture was stirred for $20 \mathrm{~h}$ at $110{ }^{\circ} \mathrm{C}$. The product was isolated using semi-preparative HPLC. Yield $167 \mathrm{mg}(68 \%)$ of 3 as a ca. 1 to 1 mixture of 3 -(2-methyl-1H-inden-4-yl)-1H-indole (3a) and 3-(2-methyl-1H-inden-7-yl)-1H-indole (3b). Anal. calc. for $\mathrm{C}_{18} \mathrm{H}_{15} \mathrm{~N}$ : C, 88.13; $\mathrm{H}, 6.16$. Found: $\mathrm{C}, 88.02 ; \mathrm{H}, 5.89 .{ }^{1} \mathrm{H} \mathrm{NMR}\left(\mathrm{CDCl}_{3}\right): \delta 8.20$ (br.s, $2 \mathrm{H}$ in $\mathbf{3 a}$ and $\mathbf{3 b}), 7.74(\mathrm{~m}, 1 \mathrm{H}$ in $\mathbf{3 a}$ or $\mathbf{3 b}), 7.14-7.46(\mathrm{~m}, 15 \mathrm{H}$ in $\mathbf{3 a}$ and $\mathbf{3 b}) 6.64(\mathrm{~m}, 1 \mathrm{H}$ in $\mathbf{3 b}), 6.56(\mathrm{~m}, 1 \mathrm{H}$ in 3a), $3.40(\mathrm{~m}, 2 \mathrm{H}$ in $3 \mathbf{a}), 3.35(\mathrm{~m}, 2 \mathrm{H}$ in $\mathbf{3 b}), 2.14(\mathrm{~m}, 6 \mathrm{H}$ in $\mathbf{3 a}$ and $\mathbf{3 b}) .{ }^{13} \mathrm{C}\left\{{ }^{1} \mathrm{H}\right\} \mathrm{NMR}\left(\mathrm{CDCl}_{3}\right): \delta 146.4$, $146.0,145.7,144.4,144.3,144.0$ (2), 141.4, 137.6, 136.2, 136.1, 130.5, 127.3, 127.0, 126.7, 124.8, $123.8,122.5,122.4,122.3,122.2,121.6,120.4,120.2,119.9,118.1,117.0,115.7,111.3,111.1,43.2$, $43.1,16.8,16.7$.

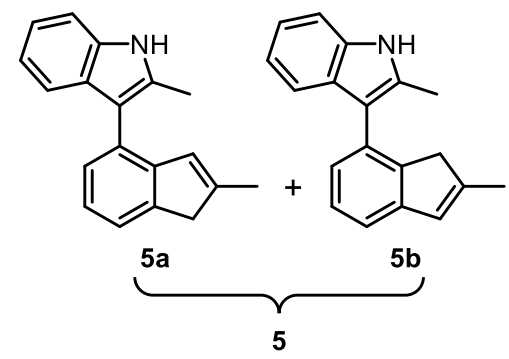

A mixture of 2-methyl-3-(2-methyl-1H-inden-4-yl)-1H-indole and 2-methyl-3-(2-methyl-1H-inden-7-yl)-1Hindole (5). A mixture of $131 \mathrm{mg}(1.0 \mathrm{mmol})$ of 2-methyl-1H-indole, $209 \mathrm{mg}(1.0 \mathrm{mmol})$ of $1,160 \mathrm{mg}(2.0$ $\mathrm{mmol})$ of lithium tert-butoxide, $10.2 \mathrm{mg}(0.02 \mathrm{mmol})$ of $\mathrm{Pd}\left(\mathrm{P}^{t} \mathrm{Bu}_{3}\right)_{2}$, and $3 \mathrm{ml}$ of toluene was stirred for $1 \mathrm{~h}$ at $110{ }^{\circ} \mathrm{C}$. The product was isolated using semipreparative HPLC. Yield $200 \mathrm{mg}(77 \%)$ of 5 as a ca. 1 to 1 mixture of 2-methyl-3-(2-methyl-1H-inden-4-yl)-1H-indole (5a) and 2-methyl-3-(2-methyl-1 $H$-inden-7yl)- $1 \mathrm{H}$-indole (5b). Anal. calc. for $\mathrm{C}_{19} \mathrm{H}_{17} \mathrm{~N}$ : C, 87.99; $\mathrm{H}, 6.61$. Found: $\mathrm{C}, 88.14 ; \mathrm{H}, 6.72 .{ }^{1} \mathrm{H}$ NMR $\left(\mathrm{CDCl}_{3}\right)$ : $\delta 7.81$ (br.s, $2 \mathrm{H}$ in $\mathbf{5 a}$ and $\mathbf{5 b}$ ), 7.13-7.28 (m, 14H in 5a and $\mathbf{5 b}), 6.65(\mathrm{~m}, 1 \mathrm{H}$ in $\mathbf{5 a}), 6.44(\mathrm{~m}, 1 \mathrm{H}$ in $5 \mathbf{b})$, 3.47 (s, 2H in 5b), 3.30 (d, $J=22.6 \mathrm{~Hz}, 1 \mathrm{H}$ in 5a), 3.15 (d, $J=22.6 \mathrm{~Hz}, 1 \mathrm{H}$ in $5 \mathbf{a}$ ), 2.40 (s, 3H in $5 \mathbf{b}$ ), 2.36 (s, 3H in 5a), 2.18 (s, 3H in 5b), 2.17 (s, 3H in 5a). ${ }^{13} \mathrm{C}\left\{{ }^{1} \mathrm{H}\right\} \operatorname{NMR}\left(\mathrm{CDCl}_{3}\right): \delta 146.2,146.1,145.3,145.2$, $143.7,143.1,135.2,131.7,131.5,130.4,128.5,128.4,128.0,127.4,127.1,126.7,126.4,126.3,123.6$, $121.6,121.1,119.6,119.5,119.4,119.2,118.4,113.7,113.5,110.3,110.2,43.0,42.9,16.8,16.7,12.37$, 12.36 . 


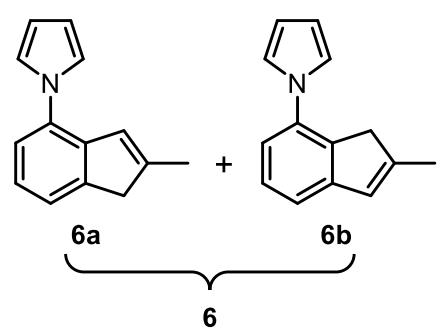

A mixture of 1-(2-methyl-1H-inden-4-yl)pyrrole and 1-(2-methyl-1H-inden-7-yl)pyrrole (6). A solution of $15.2 \mathrm{~g}(227 \mathrm{mmol})$ of pyrrole in $300 \mathrm{ml}$ of toluene was metallated with $80.0 \mathrm{ml}$ of $2.5 \mathrm{M}^{n} \mathrm{BuLi}(200 \mathrm{mmol})$ in hexanes by vigorous stirring at $0{ }^{\circ} \mathrm{C}$. The resulted mixture was warmed to room temperature and stirred for $15 \mathrm{~min}$; then, hexanes were distilled off in vacuum. To the residue, a solution of $37.6 \mathrm{~g} \mathrm{(180}$ $\mathrm{mmol})$ of $1 \mathrm{in} 150 \mathrm{ml}$ of toluene was added; then, $898 \mathrm{mg}(4.0 \mathrm{mmol})$ of $\mathrm{Pd}(\mathrm{OAc})_{2}$ and $1.79 \mathrm{~g}(6.0 \mathrm{mmol})$ of 2-[di(tert-butyl)phosphino]-1,1'-biphenyl were added. This resulting mixture was refluxed for 1 hour and then cooled to ambient temperature. The solution was decanted, and the precipitate was additionally washed by $3 \times 100 \mathrm{ml}$ of methyl-tert-butyl ether. The combined extract was evaporated using a rotary evaporator. The residue was dissolved in $100 \mathrm{ml}$ of hexanes. This solution was passed through a short column with Silica Gel $60(40-63 \mu \mathrm{m}, \mathrm{d} 60 \mathrm{~mm}$, I $150 \mathrm{~mm}$; eluent: hexanes/dichloromethane $=2 / 1$, vol). Vacuum distillation of the crude product gave yellowish oil, b.p. $145^{\circ} \mathrm{C} / 5 \mathrm{~mm} \mathrm{Hg}$. Yield $29.2 \mathrm{~g}(83 \%)$ of a ca. 1 to 1 mixture of 1-(2-methyl-1H-inden-4-yl)pyrrole (6a) and 1-(2-methyl-1H-inden-7-yl)pyrrole (6b). Anal. calc. for $\mathrm{C}_{14} \mathrm{H}_{13} \mathrm{~N}$ : C, 86.12; $\mathrm{H}, 6.71$. Found: $\mathrm{C}, 86.25 ; \mathrm{H}, 6.76 .{ }^{1} \mathrm{H}$ NMR $\left(\mathrm{CDCl}_{3}\right): \delta 7.23-7.29(\mathrm{~m}$, $2 \mathrm{H}$ in $\mathbf{6 a}$ and $\mathbf{6 b}), 7.03-7.17(\mathrm{~m}, 4 \mathrm{H}$ in $6 \mathbf{a}$ and $\mathbf{6 b}), 7.04(\mathrm{dd}, J=7.9 \mathrm{~Hz}, J=1.0 \mathrm{~Hz}, 1 \mathrm{H}$ in $6 \mathbf{b}), 7.01(\mathrm{t}, J=$ $2.2 \mathrm{~Hz}, 2 \mathrm{H}$ in $6 \mathbf{b}), 6.96(\mathrm{t}, J=2.2 \mathrm{~Hz}, 2 \mathrm{H}$ in $6 \mathbf{a}), 6.62(\mathrm{~m}, 1 \mathrm{H}$ in $6 \mathbf{a}), 6.48(\mathrm{~m}, 1 \mathrm{H}$ in $6 \mathbf{b}), 6.33(\mathrm{t}, J=2.2$ $\mathrm{Hz}, 2 \mathrm{H}$ in $6 \mathbf{a}), 6.32(\mathrm{t}, J=2.2 \mathrm{~Hz}, 2 \mathrm{H}$ in $6 \mathbf{b}), 3.36(\mathrm{~m}, 2 \mathrm{H}$ in $6 \mathbf{b}), 3.33(\mathrm{~m}, 2 \mathrm{H}$ in $6 \mathbf{a}), 2.11(\mathrm{~m}, 6 \mathrm{H}$ in $6 \mathbf{a}$ and 6b). ${ }^{13} \mathrm{C}\left\{{ }^{1} \mathrm{H}\right\} \mathrm{NMR}\left(\mathrm{CDCl}_{3}\right): \delta 148.0,147.1,146.6,145.2,139.4,136.8,135.4,133.2,127.8,127.0,124.3$, $121.7,121.6,121.3,120.7,118.9,118.1,109.15,109.12,43.0,41.9,16.7,16.5$.

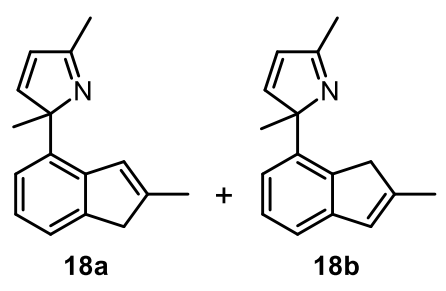

A mixture of 2,5-dimethyl-2-(2-methyl-1H-inden-4-yl)-2H-pyrrole and 2,5-dimethyl-2-(2-methyl-1H-inden7-yl)-2 $\mathrm{H}$-pyrrole. A mixture of $95 \mathrm{mg}(1.0 \mathrm{mmol})$ of 2,5-dimethyl-1 $\mathrm{H}$-pyrrole, $209 \mathrm{mg}(1.0 \mathrm{mmol})$ of 1, 240 $\mathrm{mg}(3.0 \mathrm{mmol})$ of lithium tert-butoxide, $10.2 \mathrm{mg}(0.02 \mathrm{mmol})$ of $\mathrm{Pd}\left(\mathrm{P}^{\prime} \mathrm{Bu}_{3}\right)_{2}$, and $3.0 \mathrm{ml}$ of toluene was stirred for $14 \mathrm{~h}$ at $110{ }^{\circ} \mathrm{C}$. The product was isolated using semi-preparative HPLC, yielding $127 \mathrm{mg}$ (57\%) of $\sim 1: 1$ mixture of 2,5-dimethyl-2-(2-methyl- $1 H$-inden-4-yl)-2H-pyrrole (18a) and 2,5-dimethyl-2-(2methyl-1H-inden-7-yl)-2H-pyrrole (18b). Anal. calc. for $\mathrm{C}_{16} \mathrm{H}_{17} \mathrm{~N}$ : C, 86.05; $\mathrm{H}, 7.67$. Found: $\mathrm{C}, 86.19 ; \mathrm{H}$, 7.77. ${ }^{1} \mathrm{H}$ NMR $\left(\mathrm{CDCl}_{3}\right): \delta 7.73(\mathrm{~d}, J=4.84 \mathrm{~Hz}, 1 \mathrm{H} \mathrm{18b}), 7.60(\mathrm{~d}, J=4.84 \mathrm{~Hz}, 1 \mathrm{H}$ in 18a), 7.30 (d, $J=7.80$ $\mathrm{Hz}, 1 \mathrm{H}$ in 18b), 7.27-7.21 (m, $2 \mathrm{H}$ in $18 \mathrm{a}$ and $18 \mathrm{~b}$ ), 7.17 (dd, $J=7.33 \mathrm{~Hz}, J=7.49 \mathrm{~Hz}, 1 \mathrm{H}$ in $18 \mathrm{a}$ ), 7.14 $7.11(\mathrm{~m}, 1 \mathrm{H}$ in 18b), $7.01 \mathrm{~d}, J=7.49 \mathrm{~Hz}, 1 \mathrm{H}$ in 18a), 6.99-6.96 (m, $1 \mathrm{H}$ in 18a), 6.44-6.41 (m, $1 \mathrm{H}$ in 18b), 6.27 (d, $J=4.84 \mathrm{~Hz}, 1 \mathrm{H}$ in 18b), $6.23(\mathrm{~d}, J=4.84 \mathrm{~Hz}, 1 \mathrm{H}$ in 18a), 3.37 (s, 2H in 18b), 3.25 (s, $2 \mathrm{H}$ in 18a), 2.31 (s, 6H in 18a and 18b), 2.18 (s, 3H in 18b), 2.12 (s, 3H in 18a), 1.66 (s, 6H in 18a and 18b). ${ }^{13} \mathrm{C}\left\{{ }^{1} \mathrm{H}\right\}$ NMR $\left(\mathrm{CDCl}_{3}\right): \delta 170.8,170.5,159.94,159.87,147.0,145.8,145.7,144.4,143.3,140.3$, 135.6, 132.9, 127.4, 126.8, 126.73, 126.65, 126.61, 124.2, 123.5, 122.6, 122.2, 118.9, 44.1, 43.2, 43.0, $42.3,24.7,23.9,18.9,18.8,16.9,16.5$. 

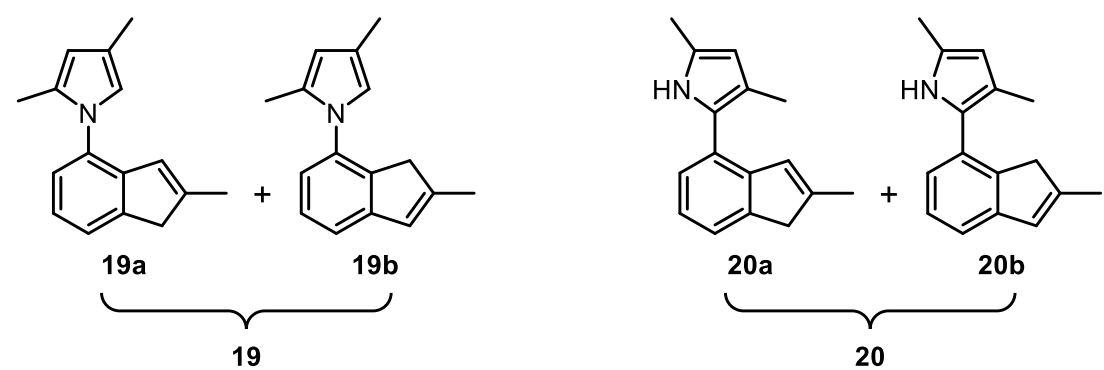

A mixture of 2,4-dimethyl-1-(2-methyl-1H-inden-4-yl)-1H-pyrrole and 2,4-dimethyl-1-(2-methyl-1H-inden7-yl)-1H-pyrrole. A mixture of $95 \mathrm{mg}(1.0 \mathrm{mmol})$ of 2,4-dimethyl-1H-pyrrole, $209 \mathrm{mg}(1.0 \mathrm{mmol})$ of 1, 240 $\mathrm{mg}(3.0 \mathrm{mmol})$ of lithium tert-butoxide, $10.2 \mathrm{mg}(0.02 \mathrm{mmol})$ of $\mathrm{Pd}\left(\mathrm{P}^{t} \mathrm{Bu}_{3}\right)_{2}$, and $3.0 \mathrm{ml}$ of toluene was stirred for $14 \mathrm{~h}$ at $110{ }^{\circ} \mathrm{C}$. The products were isolated using semi-preparative HPLC. Yields: 19, 30\% (67 $\mathrm{mg}) ; 20,59 \%$ (132 mg). Product 19 is a mixture of 2,4-dimethyl-1-(2-methyl- $1 \mathrm{H}$-inden-4-yl)-1H-pyrrole (19a) and 2,4-dimethyl-1-(2-methyl-1 $\mathrm{H}$-inden-7-yl)-1 $\mathrm{H}$-pyrrole (19b). Anal. calc. for $\mathrm{C}_{16} \mathrm{H}_{17} \mathrm{~N}: \mathrm{C}, 86.05 ; \mathrm{H}$, 7.67. Found: C, 86.22; $\mathrm{H}, 7.80 .{ }^{1} \mathrm{H}$ NMR $\left(\mathrm{CDCl}_{3}\right): \delta 7.30-7.27(\mathrm{~m}, 1 \mathrm{H}$ in $19 \mathrm{~b}), 7.21$ (dddt, $J=7.47 \mathrm{~Hz}, J=$ $7.33 \mathrm{~Hz}, J=0.7 \mathrm{~Hz}, J=0.6 \mathrm{~Hz}, 1 \mathrm{H}$ in $19 \mathrm{a}), 7.18$ (dd, $J=7.42 \mathrm{~Hz}, J=1.52 \mathrm{~Hz}, 1 \mathrm{H}$ in 19a), 7.08 (dd, $J=$ $7.85 \mathrm{~Hz}, J=6.94 \mathrm{~Hz}, 1 \mathrm{H}$ in 19b), 7.05-7.02 (m, $1 \mathrm{H}$ in 19b), 6.90 (dd, $1 \mathrm{H}, J=7.33 \mathrm{~Hz}, J=1.52 \mathrm{~Hz}, 1 \mathrm{H}$ in 19a), 6.48-6.46 (m, 1H in 19b), 6.45-6.43 (m, 2H in 19a and 19b), 6.29-6.27 (m, 1H in 19a), 5.86-5.83 (m, $2 \mathrm{H}$ in 19a and 19b), 3.31 (dq, $J=1.53 \mathrm{~Hz}, J=0.8 \mathrm{~Hz}, 2 \mathrm{H}$ in 19b), 3.14 (dq, $J=1.53 \mathrm{~Hz}, J=0.6 \mathrm{~Hz}$, $2 \mathrm{H}$ in 19a), 2.10-2.09 (m, 6H in 19a), 2.08-2.06 (m, 6H in 19b), 2.02 (d, J=0.8 Hz, 3H in 19b), 2.01 (d, $J=0.9 \mathrm{~Hz}, 3 \mathrm{H}$ in 19a). ${ }^{13} \mathrm{C}\left\{{ }^{1} \mathrm{H}\right\} \operatorname{NMR}\left(\mathrm{CDCl}_{3}\right): \delta 148.3,148.0,147.6,145.4,143.5,140.8,136.7,132.9$, 130.4, 129.9, 128.1, 127.8, 125.51, 125.52, 124.83, 124.82,123.5, 123.1, 120.4, 119.8, 119.0, 118.8, 109.6, 109.6, 44.0, 42.0, 32.4, 23.5, 17.6, 17.4, 13.3, 13.1. Product 20 is a mixture of 3,5-dimethyl-2-(2methyl-1H-inden-4-yl)-1H-pyrrole (20a) and 3,5-dimethyl-2-(2-methyl-1H-inden-7-yl)-1H-pyrrole (20b). Anal. calc. for $\mathrm{C}_{16} \mathrm{H}_{17} \mathrm{~N}$ : C, 86.05; $\mathrm{H}, 7.67$. Found: $\mathrm{C}, 85.97 ; \mathrm{H}, 7.79 .{ }^{1} \mathrm{H}$ NMR $\left(\mathrm{CDCl}_{3}\right): \delta 7.41(\mathrm{br} . \mathrm{s}, 1 \mathrm{H}$, $\mathrm{NH}$ of 20a), 7.36 (br.s, $1 \mathrm{H}, \mathrm{NH}$ of $20 \mathrm{~b}$ ), 7.17 (dd, $J=7.17 \mathrm{~Hz}, J=1.0 \mathrm{~Hz}, 1 \mathrm{H}$ in 20a), 7.15 (dd, $J=7.63$ $\mathrm{Hz}, J=7.47 \mathrm{~Hz}, 1 \mathrm{H}$ in 20b), 7.10 (dd, $J=7.17 \mathrm{~Hz}, J=7.63 \mathrm{~Hz}, 1 \mathrm{H}$ in 20a), 7. 08 (dd, $J=7.47 \mathrm{~Hz}, J=1.0$ $\mathrm{Hz}, 1 \mathrm{H}$ in 20b), 7.06 (dd, $J=7.63 \mathrm{~Hz}, J=1.1 \mathrm{~Hz}, 1 \mathrm{H}$ in 20a), 6.97 (dd, $J=7.63 \mathrm{~Hz}, J=1.2 \mathrm{~Hz}, 1 \mathrm{H}$ in 20b), 6.48-6.45 (m, $1 \mathrm{H}$ in 20a), 6.41-6.38 (m, $1 \mathrm{H}$ in 20b), 5.76 (d, J=2.9 Hz, $1 \mathrm{H}$ in 20a ), 5.75 (d, $J=$ $2.9 \mathrm{~Hz}, 1 \mathrm{H}$ in 20b), 3.19 (s, 2H in 20a), 3.07 (s, 2H in 20b), 2.12 (d, $J=0.6 \mathrm{~Hz}, 3 \mathrm{H}$ in 20a), 2.11 (d, $J=$ $0.6 \mathrm{~Hz}, 3 \mathrm{H}$ in 20b), 2.05-2.04 (m, 6H in 20a), 2.03 (s, 3H in 20b), 2.01 (d, J=1.2 Hz, 3H in 20b). ${ }^{13} \mathrm{C}\left\{{ }^{1} \mathrm{H}\right\}$ NMR $\left(\mathrm{CDCl}_{3}\right): \delta 146.3,146.1,146.0,143.8,143.6,140.6,129.2,128.5,128.1,127.1,126.9,126.8$, $126.6,126.4,125.5,124.4,123.5,121.5,118.2,116.3,116.0,109.0,108.8,108.5,42.8,42.6,16.7$, $16.5,13.2,12.9,12.2,11.9$.

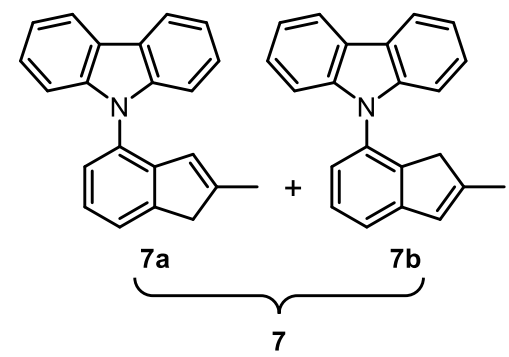

A mixture of 9-(2-methyl-1H-inden-4-yl)carbazole and 9-(2-methyl-1H-inden-7-yl)carbazole (7). To a

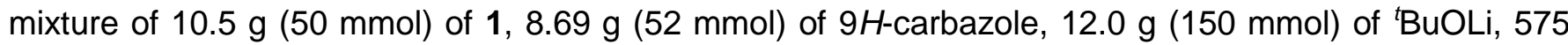
$\mathrm{mg}(2.0 \mathrm{mmol})$ of $\mathrm{Pd}(\mathrm{dba})_{2}$ and $404 \mathrm{mg}(2.0 \mathrm{mmol})$ of tri(tert-butyl)phosphine in $150 \mathrm{ml}$ of toluene were added. The resulting mixture was refluxed for 12 hours, cooled to ambient temperature, and then added to $100 \mathrm{ml}$ of cold water. The organic layer was separated, and the aqueous layer was washed by $2 \times 150$ $\mathrm{ml}$ of dichloromethane. The combined extract was dried over $\mathrm{Na}_{2} \mathrm{SO}_{4}$ and evaporated to dryness. The

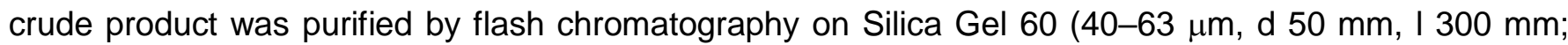


eluent: hexanes). Yield: $8.12 \mathrm{~g}(55 \%)$ of yellow oil of a ca. 1 to 1 mixture of 9 -(2-methyl-1H-inden-4yl)carbazole (7a) and 9-(2-methyl-1H-inden-7-yl)carbazole (7b). Anal. calc. for $\mathrm{C}_{22} \mathrm{H}_{17} \mathrm{~N}$ : $\mathrm{C}, 89.46 ; \mathrm{H}$, 5.80. Found: $\mathrm{C}, 89.60 ; \mathrm{H}, 5.87 .{ }^{1} \mathrm{H}$ NMR $\left(\mathrm{CDCl}_{3}\right): \delta 8.14(\mathrm{~m}, 4 \mathrm{H}$ in $7 \mathrm{a}$ and $7 \mathrm{~b}), 7.10-7.46(\mathrm{~m}, 18 \mathrm{H}$ in $7 \mathrm{a}$ and 7b), 6.54 (m, 1H in 7a), 6.01 (m, 1H in 7b), 3.40 (s, 2H in 7b), 2.97 (s, 2H in 7a), 2.01 (m, 3H in 7b), $2.00(\mathrm{~m}, 3 \mathrm{H}$ in $7 \mathrm{a}) .{ }^{13} \mathrm{C}\left\{{ }^{1} \mathrm{H}\right\} \mathrm{NMR}\left(\mathrm{CDCl}_{3}\right): \delta 148.3,147.28,147.23,146.9,145.5,143.6,141.25,141.21$, $140.88,140.85,140.7,132.5,128.1,127.0,125.7,125.6,124.9,124.7,123.5,122.9,120.3,120.2$, $119.8,119.5,110.2,110.0,43.2,41.3,16.7,16.5 .{ }^{13} \mathrm{C}\left\{{ }^{1} \mathrm{H}\right\} \operatorname{NMR}\left(\mathrm{CDCl}_{3}\right): \delta 148.3,147.28,147.23,146.9$, $145.5,143.6,141.25,141.21,140.88,140.85,140.7,132.5,128.1,127.0,125.7,125.6,124.9,124.7$, $123.5,122.9,120.3,120.2,119.8,119.5,110.2,110.0,43.2,41.3,16.7,16.5$.

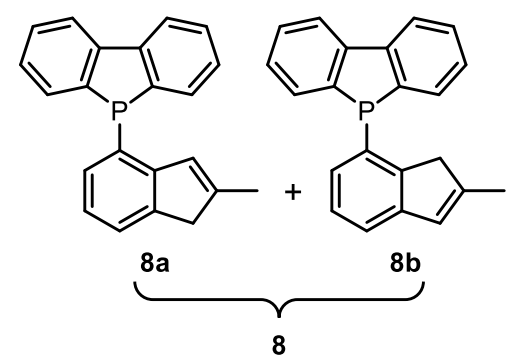

A mixture of 5-(2-methyl-1H-inden-4-yl)benzo[b]phosphindole and 5-(2-methyl-1H-inden-7-yl)benzo[b]phosphindole (8). A solution of indene 1 (2.00 g, $9.6 \mathrm{mmol})$, and 1,2-dibromoethane $(1.80 \mathrm{~g}, 9.6$ $\mathrm{mmol})$ in THF $(25 \mathrm{ml})$ was added to $\mathrm{Mg}$ powder $(510 \mathrm{mg}, 21 \mathrm{mmol})$ in THF $(5 \mathrm{ml})$ for $30 \mathrm{~min}$. The mixture was refluxed for additional $1 \mathrm{~h}$ and cooled to $0^{\circ} \mathrm{C}$. Then, a solution of 5 -chlorodibenzophosphole $(2.02 \mathrm{~g}$, $9.6 \mathrm{mmol})$ in THF $(10 \mathrm{ml})$ was added and the mixture was refluxed for $5 \mathrm{~h}$. On cooling to room temperature, the mixture was poured into aqueous solution of $\mathrm{NH}_{4} \mathrm{Cl}$. The organic phase was separated and the aqueous layer was extracted with EtOAc. The combined organic solutions were dried over $\mathrm{Na}_{2} \mathrm{SO}_{4}$ and the solvents were removed in vacuum. Recrystallization of the residue from EtOAc-MeOH $(20: 1, \mathrm{v} / \mathrm{v})$ afforded $1.78 \mathrm{~g}(57 \%)$ of the product as a brownish solid. According to ${ }^{1} \mathrm{H} \mathrm{NMR}$, the product was a $\sim 1: 1$ mixture of $\underline{5}$-(2-methyl-1 $H$-inden-4-yl)benzo[b]phosphindole (8a) and 5-(2-methyl-1 $H$-inden-7yl)-benzo[b]phosphindole (8b). Anal. calc. for $\mathrm{C}_{22} \mathrm{H}_{17} \mathrm{P}$ : C, 84.60; $\mathrm{H}, 5.49$. Found: $\mathrm{C}, 84.44 ; \mathrm{H}, 5.53$. ${ }^{1} \mathrm{H}$ $\operatorname{NMR}\left(\mathrm{CDCl}_{3}\right): \delta 8.01-7.96(\mathrm{~m}, 2 \mathrm{H}$ in $\mathbf{8 a}$ and $2 \mathrm{H}$ in $\mathbf{8 b}), 7.72-7.65(\mathrm{~m}, 2 \mathrm{H}$ in $\mathbf{8 a}$ and $2 \mathrm{H}$ in $\mathbf{8 b}), 7.51-7.43$ (m, $2 \mathrm{H}$ in $8 \mathbf{a}$ and $2 \mathrm{H}$ in $8 \mathbf{b}), 7.32-7.26(\mathrm{~m}, 3 \mathrm{H}$ in $8 \mathbf{a}$ and $2 \mathrm{H}$ in $8 b), 7.18(\mathrm{~d}, J=7.5 \mathrm{~Hz}, 1 \mathrm{H}$ in $8 \mathbf{b}), 7.04$ (t, $J=7.5 \mathrm{~Hz}, 1 \mathrm{H}$ in $8 \mathrm{~b}$ ), 6.97 (br.s, $1 \mathrm{H}$ in $8 \mathrm{a}$ ), 6.83 (t, $J=7.5 \mathrm{~Hz}, 1 \mathrm{H}$ in $8 \mathbf{a}), 6.66$ (t, $J=7.3 \mathrm{~Hz}, 1 \mathrm{H}$ in $8 \mathbf{a}$ ), 6.43 (br.s, $1 \mathrm{H}$ in 8b), 3.29 (br.s, 3H in 8a), 3.10 (br.s, 3H in 8b), 2.19 (br.s, 3H in 8a), 2.08 (br.s, 3H in 8b). ${ }^{31} \mathrm{P} \mathrm{NMR}\left(\mathrm{CDCl}_{3}\right): \delta-16.15,-18.22$.

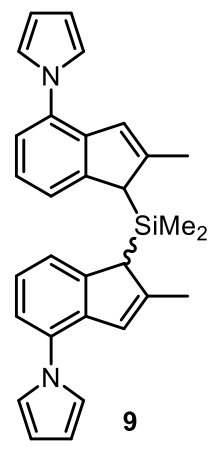

A mixture of rac- and meso-bis[2-methyl-4-(pyrrol-1-yl)-1H-inden-1-yl](dimethyl)silanes (9). To a solution of $19.8 \mathrm{~g}(101 \mathrm{mmol})$ of 6 in a mixture of $200 \mathrm{ml}$ of toluene and $10 \mathrm{ml}$ of THF, $40.5 \mathrm{ml}$ of $2.5 \mathrm{M}{ }^{n} \mathrm{BuLi}$ $(47.8 \mathrm{mmol})$ in hexanes was added at $10^{\circ} \mathrm{C}$. This mixture was stirred for $1 \mathrm{~h}$ at $20^{\circ} \mathrm{C}$ and then cooled to $0{ }^{\circ} \mathrm{C}$. At this temperature, $6.14 \mathrm{ml}(6.53 \mathrm{~g}, 50.6 \mathrm{mmol})$ of $\mathrm{Me}_{2} \mathrm{SiCl}_{2}$ was added. The resulting mixture was stirred for $3 \mathrm{~h}$ at ambient temperature and then for 1 hour at reflux. Further on, $100 \mathrm{ml}$ of water was added. The organic layer was separated. The aqueous layer was washed by $2 \times 200 \mathrm{ml}$ of methyl-tert- 
butyl ether. The combined extract was dried over $\mathrm{K}_{2} \mathrm{CO}_{3}$ and evaporated to dryness. The crude product was purified by flash chromatography on Silica Gel $60(40-63 \mu \mathrm{m}$, d $40 \mathrm{~mm}, \mathrm{~h} 300 \mathrm{~mm}$; eluent: hexanes/dichloromethane, 2:1, vol.). Yield: $13.7 \mathrm{~g}(61 \%)$ of white solid of a ca. 1 to 1 mixture of rac- and meso-compounds. Anal. calc. for $\mathrm{C}_{30} \mathrm{H}_{30} \mathrm{~N}_{2} \mathrm{Si}$ : C, 80.67; $\mathrm{H}, 6.77$. Found: $\mathrm{C}, 80.84 ; \mathrm{H}, 6.82$. ${ }^{1} \mathrm{H}$ NMR $\left(\mathrm{CDCl}_{3}\right): \delta 7.38(\mathrm{~d}, J=7.4 \mathrm{~Hz}, 2 \mathrm{H}$ in rac- or meso-9), $7.28(\mathrm{~d}, J=7.3 \mathrm{~Hz}, 2 \mathrm{H}$ in meso- or rac-9), 7.10 $7.21(\mathrm{~m}, 8 \mathrm{H}$ in rac- and meso-9), $7.01 \mathrm{t}, J=2.1 \mathrm{~Hz}, 8 \mathrm{H}$ in rac- and meso-9), $6.77(\mathrm{~m}, 2 \mathrm{H}$ in rac- or meso-9), $6.74(\mathrm{~m}, 2 \mathrm{H}$ in meso- or rac-9), $6.36(\mathrm{t}, J=2.1 \mathrm{~Hz}, 4 \mathrm{H}$ in rac- or meso-9), 6.35 (t, $J=2.1 \mathrm{~Hz}$, $4 \mathrm{H}$ in rac- or meso-9), 3.77 (br.s, $2 \mathrm{H}$ in rac- or meso-9), 3.76 (br.s, $2 \mathrm{H}$ in meso- or rac-9), 2.23 (d, $J=1.2$ $\mathrm{Hz}, 6 \mathrm{H}$ in rac- or meso-9), $2.13(\mathrm{~d}, J=1.2 \mathrm{~Hz}, 6 \mathrm{H}$ in meso- or rac-9), -0.167 (s, 6H in rac-9), -0.17 (s, $3 \mathrm{H}$ in meso-9), -0.22 (s, 3H in meso-9). ${ }^{13} \mathrm{C}\left\{{ }^{1} \mathrm{H}\right\} \mathrm{NMR}\left(\mathrm{CDCl}_{3}\right): \delta 148.3,148.2,146.68,146.65,138.8$, $138.7,133.43$, 133.40, 124.11, 124.07, 123.57, 123.52, 121.40, 121.35, 121.29, 120.53, 120.50, 109.22, $109.18,48.0,47.9,17.9,17.8,-5.47,-5.50,-5.52$.

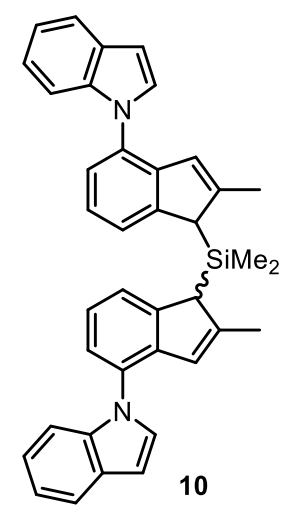

A mixture of rac- and meso-bis[2-methyl-4-(indol-1-yl)-1H-inden-1-yl](dimethyl)silanes (10). To a solution of $18.2 \mathrm{~g}(74.0 \mathrm{mmol})$ of 2 in $200 \mathrm{ml}$ of toluene, $29.6 \mathrm{ml}$ of $2.5 \mathrm{M}{ }^{n} \mathrm{BuLi}(74.0 \mathrm{mmol})$ in hexanes was added at room temperature. This mixture was stirred for $1.5 \mathrm{~h}$ at $20^{\circ} \mathrm{C}$, and then $10 \mathrm{ml}$ of THF was added. The resulted mixture was cooled to $-30{ }^{\circ} \mathrm{C}$. At this temperature, $4.49 \mathrm{ml}(4.78 \mathrm{~g}, 37.0 \mathrm{mmol})$ of $\mathrm{Me}_{2} \mathrm{SiCl}_{2}$ was added. The resulting mixture was stirred for 1 hour at ambient temperature, then for 1 hour at reflux. To this mixture, $50 \mathrm{ml}$ of water was added. The organic layer was separated. The aqueous layer was washed by $3 \times 30 \mathrm{ml}$ of ether. The combined extract was dried over $\mathrm{K}_{2} \mathrm{CO}_{3}$, and evaporated to dryness. The crude product was purified by flash chromatography on Silica Gel 60 (40-63 $\mu \mathrm{m}, \mathrm{d} 40 \mathrm{~mm}$, h $300 \mathrm{~mm}$; eluent: hexanes/dichloromethane, 2:1, vol.). Yield: $16.0 \mathrm{~g}(79 \%)$ of white solid of ca. 1 to 1 mixture of rac- and meso-compounds. Anal. calc. for $\mathrm{C}_{38} \mathrm{H}_{34} \mathrm{~N}_{2} \mathrm{Si}: \mathrm{C}, 83.47 ; \mathrm{H}, 6.27$. Found: $\mathrm{C}, 83.66 ; \mathrm{H}$, 6.35. ${ }^{1} \mathrm{H} \mathrm{NMR}\left(\mathrm{CDCl}_{3}\right): \delta 7.70-7.74(\mathrm{~m}, 4 \mathrm{H}$ in rac- and meso-10), $7.53(\mathrm{~d}, J=7.4 \mathrm{~Hz}, 2 \mathrm{H}$ in meso-10), $7.43(\mathrm{~d}, J=7.4 \mathrm{~Hz}, 2 \mathrm{H}$ in rac-10), $7.10-7.39(\mathrm{~m}, 24 \mathrm{H}$ in rac- and meso-10), $6.71(\mathrm{~m}, 4 \mathrm{H}$ in rac- and meso-10), 6.44 (m, 4H in rac- and meso-10), $3.89(\mathrm{~m}, 2 \mathrm{H}$ in meso-10), $3.87(\mathrm{~m}, 2 \mathrm{H}$ in rac-10), $2.24(\mathrm{~d}, \mathrm{~J}$ $=1.1 \mathrm{~Hz}, 6 \mathrm{H}$ in rac-10), $2.17(\mathrm{~d}, J=1.1 \mathrm{~Hz}, 6 \mathrm{H}$ in meso-10), -0.11 (s, 3H in meso-10), $-0.14(\mathrm{~s}, 6 \mathrm{H}$ in rac-10), -0.15 (s, 3H in meso-10). ${ }^{13} \mathrm{C}\left\{{ }^{1} \mathrm{H}\right\}$ NMR $\left(\mathrm{CDCl}_{3}\right): \delta 148.43,148.40,146.73,146.70,141.22$, $141.15,136.7,131.42,131.39,128.9,124.4,123.73,123.67,122.99,122.96,122.14,122.08,122.0$, $120.9,119.0,110.9,102.8,48.1,48.0,18.01,17.97,-5.5,-5.72,-5.76$. 


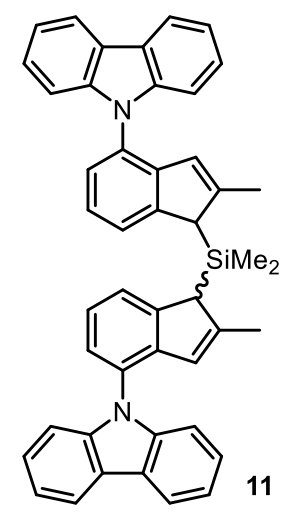

A mixture of rac- and meso-bis[2-methyl-4-(carbazol-9-yl)-1H-inden-1-yl](dimethyl)silanes (11). To a solution of $7.25 \mathrm{~g}(24.6 \mathrm{mmol})$ of 7 in $250 \mathrm{ml}$ of ether, $9.85 \mathrm{ml}$ of $2.5 \mathrm{M}{ }^{n} \mathrm{BuLi}(24.6 \mathrm{mmol})$ in hexanes was added dropwise with vigorous stirring at room temperature. This mixture was stirred for $3 \mathrm{~h}$ at room temperature and was then cooled to $-80^{\circ} \mathrm{C}$. At this temperature, $1.10 \mathrm{~g}(12.5 \mathrm{mmol})$ of $\mathrm{CuCN}$ was added. Next, the resulting mixture was stirred for $1 \mathrm{~h}$ at $0{ }^{\circ} \mathrm{C}$, and then cooled to $-80^{\circ} \mathrm{C}$. To this mixture, $1.50 \mathrm{ml}(1.62 \mathrm{~g}, 12.5 \mathrm{mmol})$ of $\mathrm{Me}_{2} \mathrm{SiCl}_{2}$ was added. The resulting mixture was stirred overnight at ambient temperature, and then $2 \mathrm{ml}$ of water was added. The resulting mixture was filtered through glass frit (G4), and the precipitate was additionally washed by $2 \times 20 \mathrm{ml}$ of ether. The combined ether filtrate was dried over $\mathrm{Na}_{2} \mathrm{SO}_{4}$ and evaporated to dryness. The crude product was washed by $3 \times 20 \mathrm{ml}$ of methanol and dried in vacuum. Yield $7.56 \mathrm{~g} \mathrm{(95 \% )} \mathrm{of} \mathrm{white} \mathrm{solid} \mathrm{of} \mathrm{ca.} 1$ to 1 mixture of rac- and mesocompounds. Anal. calc. for $\mathrm{C}_{46} \mathrm{H}_{38} \mathrm{~N}_{2} \mathrm{Si}: \mathrm{C}, 85.41 ; \mathrm{H}, 5.92$. Found: $\mathrm{C}, 85.61 ; \mathrm{H}, 6.06$. ${ }^{1} \mathrm{H} \mathrm{NMR}\left(\mathrm{CDCl}_{3}\right): \delta$ $8.19(\mathrm{~m}, 8 \mathrm{H}$ in rac- and meso-11), 7.69 ( $\mathrm{m}, 2 \mathrm{H}$ in rac-11), $7.56(\mathrm{~m}, 2 \mathrm{H}$ in meso-11), 7.25-7.44 ( $\mathrm{m}, 28 \mathrm{H}$ in rac- and meso-11), 7.12-7.17 ( $\mathrm{m}, 4 \mathrm{H}$ in rac- and meso-11), 6.19 (br.s, $4 \mathrm{H}$ in rac- and meso-11), 3.99 (br.s, 2H in rac-11), 3.95 (br.s, $2 \mathrm{H}$ in meso-11), 2.22 (d, $J=1.1 \mathrm{~Hz}, 6 \mathrm{H}$ in meso-11), $2.16(\mathrm{~d}, J=1.1 \mathrm{~Hz}$, $6 \mathrm{H}$ in rac-11), -0.098 (s, 3H in meso-11), -0.101 (s, 3H in meso-11), -0.13 (s, $6 \mathrm{H}$ in rac-11).

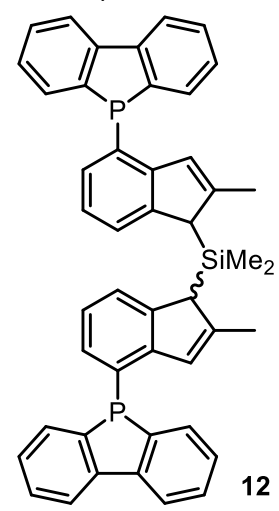

A mixture of rac- and meso- bis(4-(benzo[b]phosphindol-5-yl)-2-methyl-1H-inden-1-yl)dimethylsilanes (12). To a solution of indene $8(1.00 \mathrm{~g}, 3.2 \mathrm{mmol})$ in THF $(25 \mathrm{ml}), \mathrm{nBuLi}(1.28 \mathrm{ml} 2.5 \mathrm{M}$ in hexanes, 3.2 mmol) was added at $-78{ }^{\circ} \mathrm{C}$, and the mixture was stirred at room temperature overnight. Then, the mixture was cooled to $-78{ }^{\circ} \mathrm{C}, \mathrm{N}$-methylimidazole $\left(26 \mathrm{mg}, 0.32 \mathrm{mmol}\right.$ ) and $\mathrm{Me}_{2} \mathrm{SiCl}_{2}(206 \mathrm{mg}, 1.6 \mathrm{mmol})$ were added, and the mixture was stirred overnight at room temperature. On quenching with water and common work-up, the product was isolated by flash chromatography on silica gel (hexane- $\mathrm{CH}_{2} \mathrm{Cl}_{2}, 2: 1$, $\mathrm{v} / \mathrm{v})$. The yield was $770 \mathrm{mg}(70 \%)$. According to ${ }^{1} \mathrm{H}$ NMR, the product was a $\sim 1: 1.5$ mixture of rac- and meso- isomers. ${ }^{1} \mathrm{H} \mathrm{NMR}\left(\mathrm{CDCl}_{3}\right): \delta 8.00-7.94(\mathrm{~m}, 4 \mathrm{H}$ in rac- and meso-12), $7.72-7.64(\mathrm{~m}, 4 \mathrm{H}$ in rac- and meso-12), 7.49-7.41 (m, 4H in rac- and meso-12), 7.34-7.22 (m, 6H in rac- and meso-12), 7.11 (br.s, $2 \mathrm{H}$ in rac- and meso-12), 6.84-6.77 ( $\mathrm{m}, 2 \mathrm{H}$ in rac- and meso-12), 6.71-6.66 ( $\mathrm{m}, 2 \mathrm{H}$ in rac- and meso12), 3.69 (br.s, $2 \mathrm{H}$ in rac- and meso-12), 2.25 (d. $J=1.1 \mathrm{~Hz}, 6 \mathrm{H}$ in meso-12), 2.21 (d. $J=1.1 \mathrm{~Hz}, 6 \mathrm{H}$ in meso-12), -0.29 (s, 3H in meso-12), -0.35 (s, 3H in rac-12), -0.41 (s, 3H in meso-12). ${ }^{31} \mathrm{P} \mathrm{NMR}\left(\mathrm{CDCl}_{3}\right)$ : $\delta-17.40,-17.46$. 


\section{Details of computational studies}

All geometry optimizations were performed using Gaussian 16 [5] software with default spin DFT at the TPSSTPSS level [6] of theory employing ECP-LANL2DZ [7] basis set for Zr and correlation-consistent polarized valence double- $\zeta$ Dunning (DZ) basis sets of cc-pVDZ quality [8-10] for all other atoms, both basis sets from the EMSL basis set exchange library [11]. Single point energies were calculated at M06$2 X$ level of theory employing correlation-consistent polarized valence triple- $\zeta$ Dunning (TZ) basis sets of cc-pVTZ quality [12]. Net atomic charges and bond orders were calculated using DDEC [13] package based on Gaussian WFX output files of single point calculations. HOMOs were visualized using Gaussian Cubegen utility and GaussView software. The supplemental file om-2019-00648w-cartesian contains the computed Cartesian coordinates of all of the molecules reported in this study. The file may be opened as a text file to read the coordinates, or opened directly by a molecular modeling program such as Mercury (version 3.3 or later, http://www.ccdc.cam.ac.uk/pages/Home.aspx) for visualization and analysis.

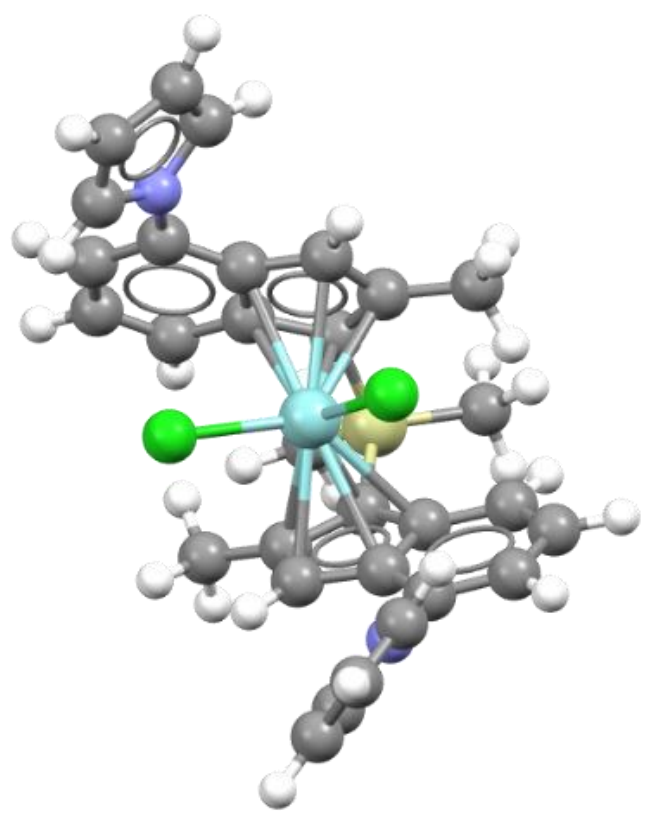

Figure S1. QM model of rac-13.
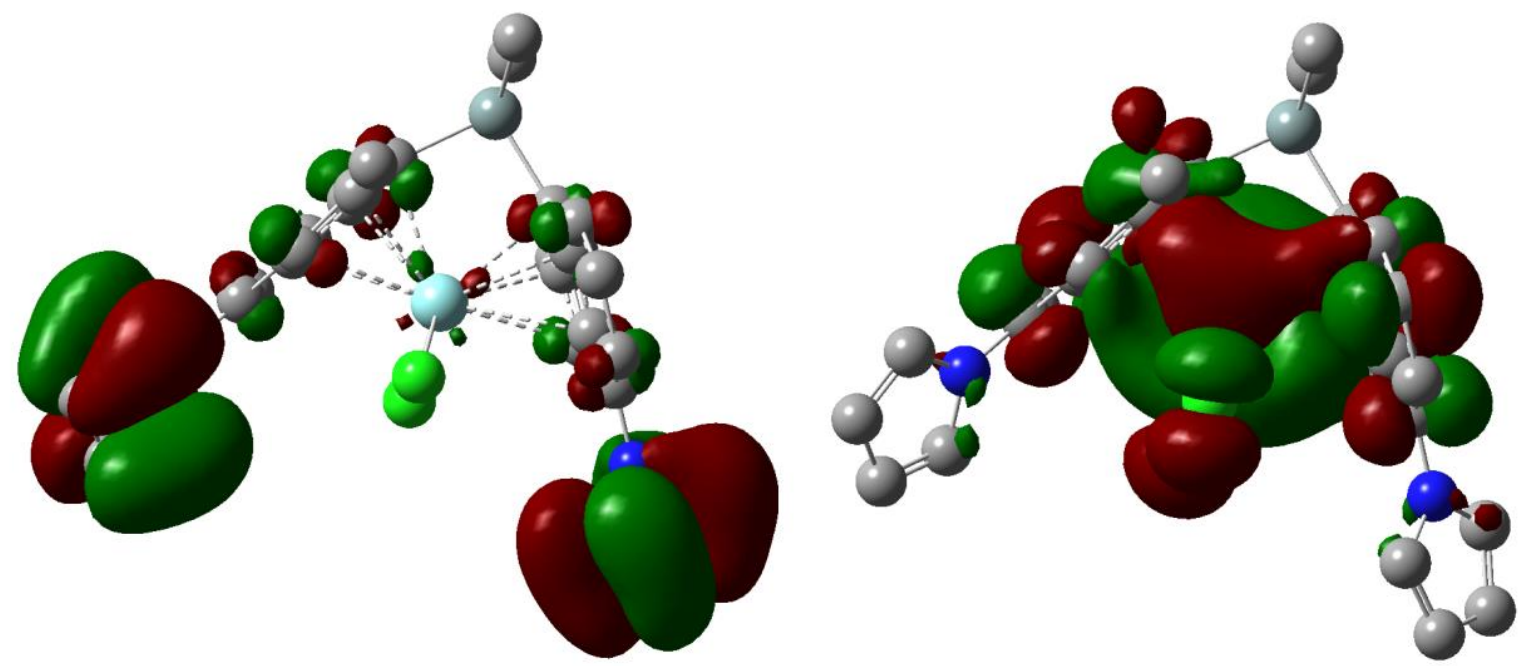

Figure S2. Rac-13 HOMO (left) and LUMO (right) visualization. 


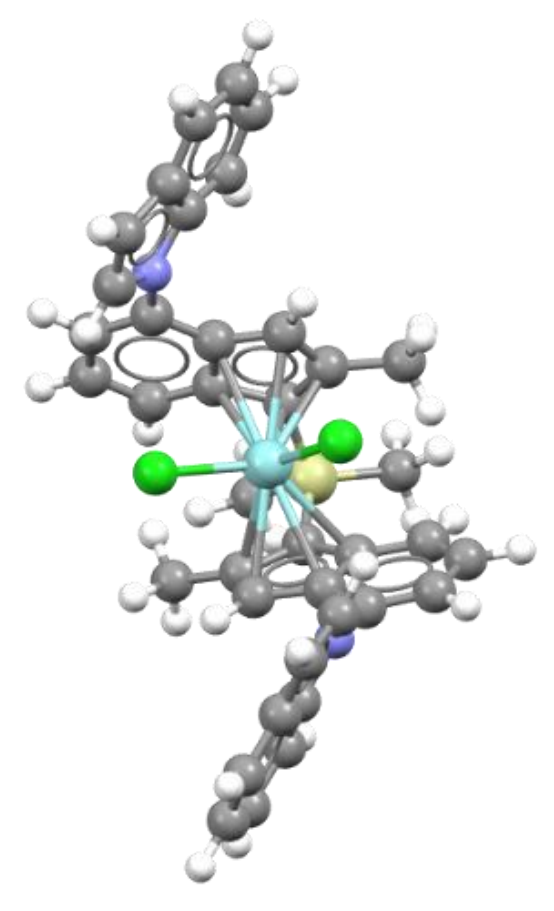

Figure S3. QM model of rac-14.

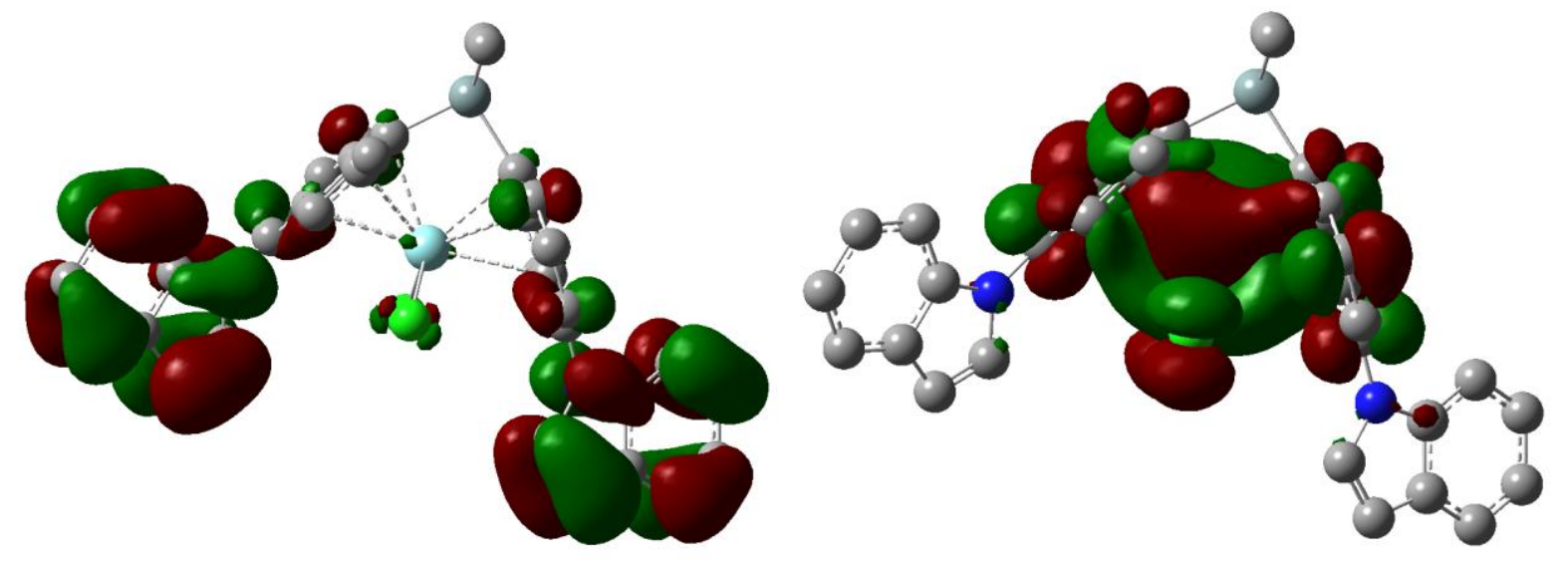

Figure S4. Rac-14 HOMO (left) and LUMO (right) visualization. 


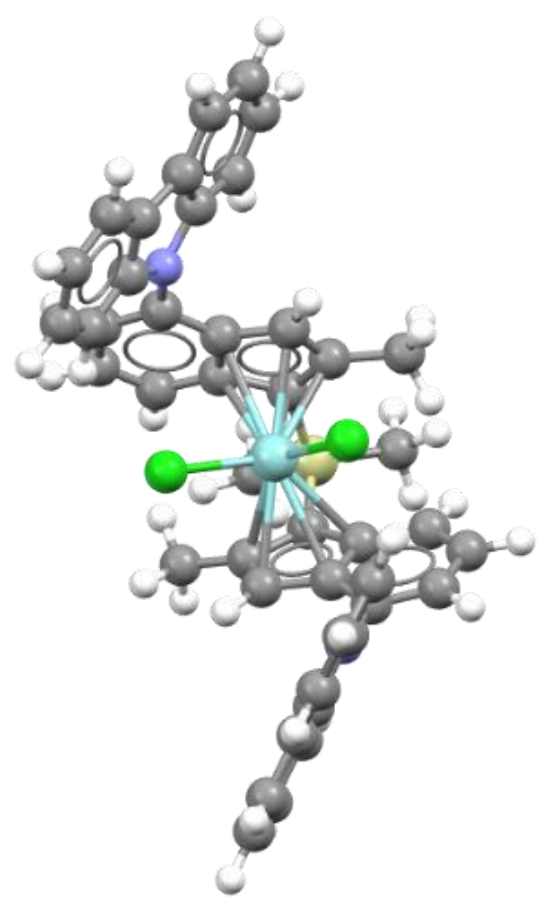

Figure S5. QM model of rac-15.
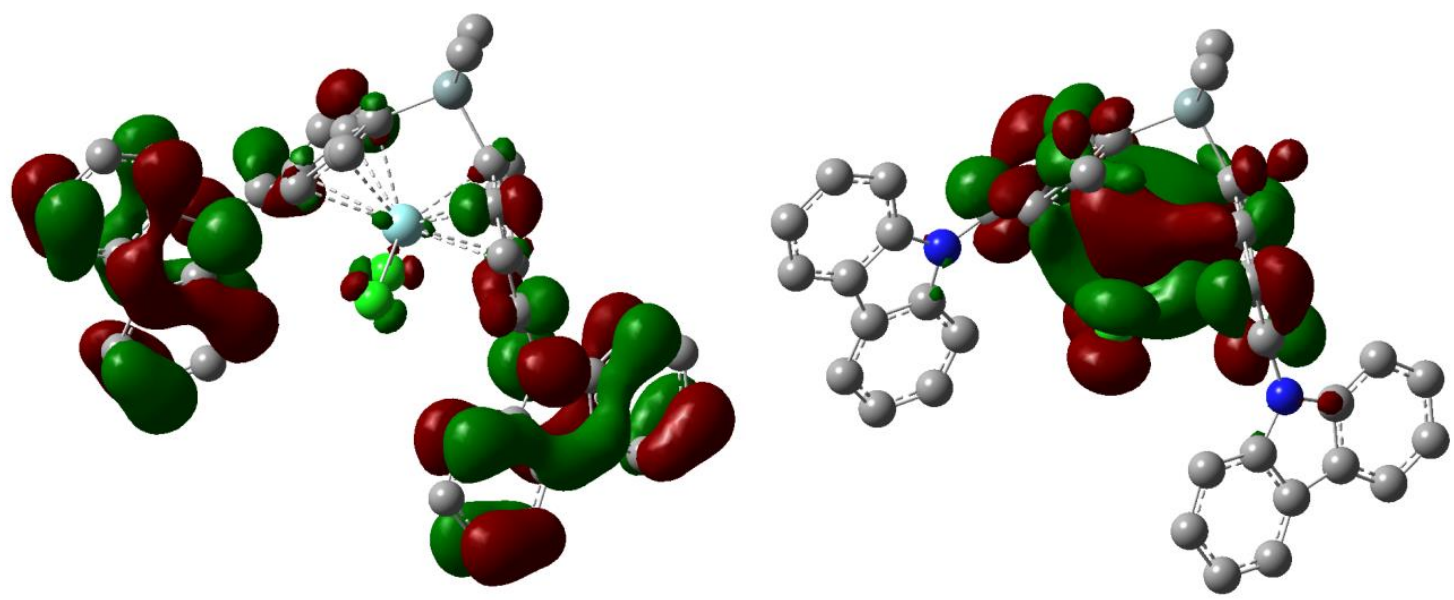

Figure S6. Rac-15 HOMO (left) and LUMO (right) visualization. 


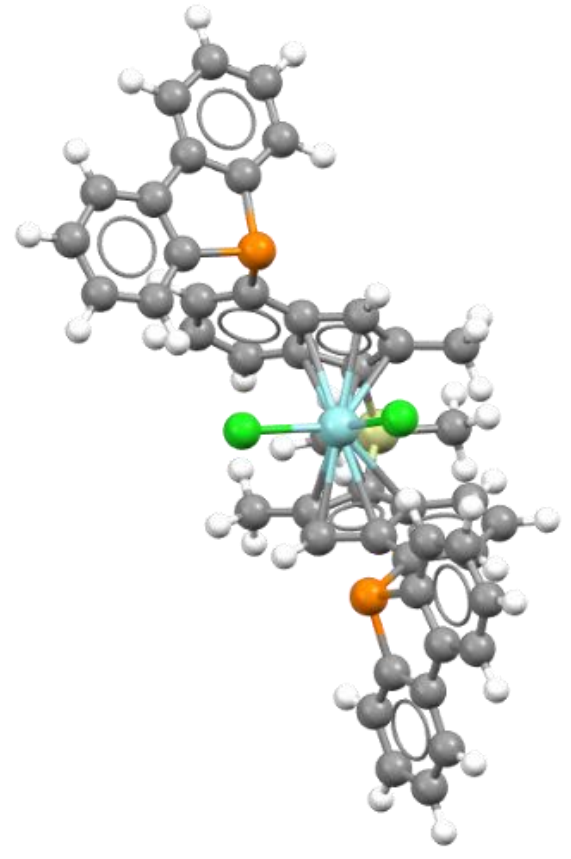

Figure S7. QM model of rac-16.
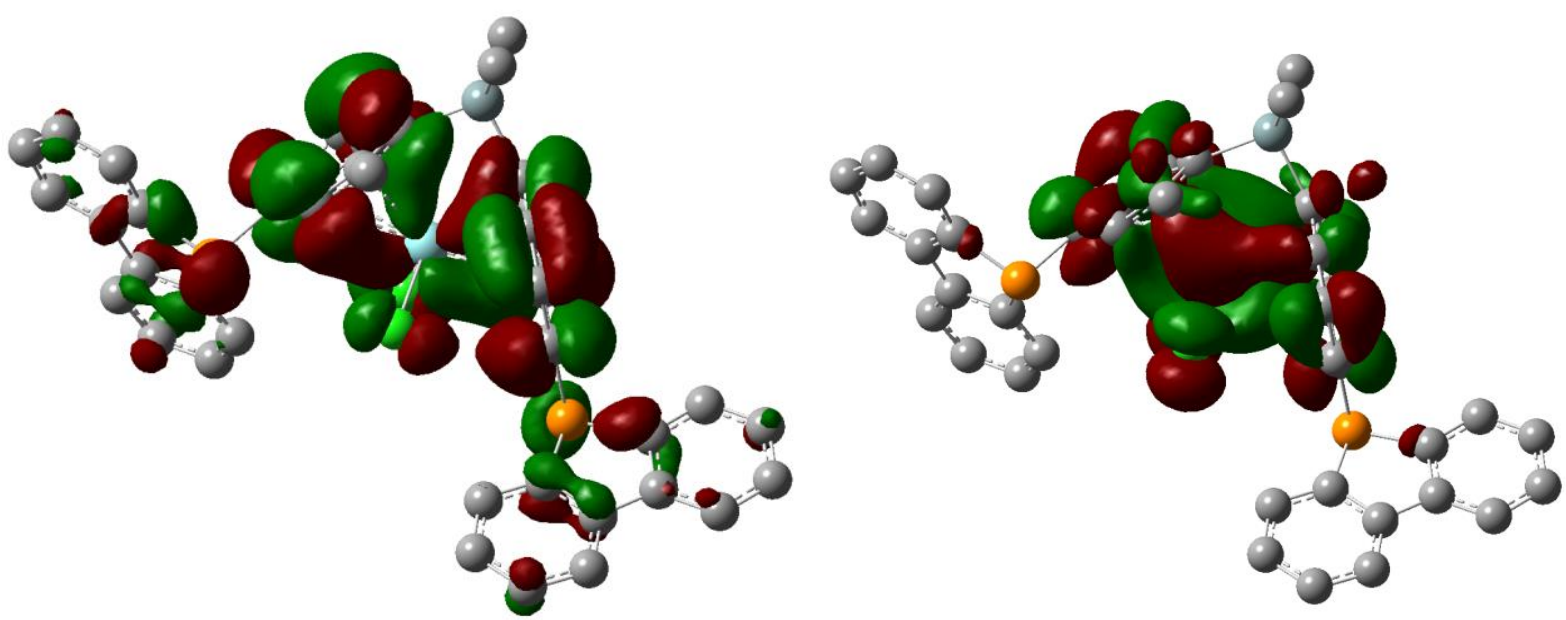

Figure S8. Rac-16 HOMO (left) and LUMO (right) visualization. 


\section{Small scale propylene polymerization experiments}

Table S1. Additional small scale propylene polymerization data

\begin{tabular}{|c|c|c|c|c|c|c|c|c|c|c|}
\hline $\begin{array}{c}\text { pre- } \\
\text { catalyst }\end{array}$ & $\begin{array}{c}\text { nprecatalyst } \\
\text { umol }\end{array}$ & $\mathrm{Al} / \mathrm{Zr}$ & solvent & $\begin{array}{l}\text { Vsolvent, } \\
\text { ul }\end{array}$ & $\begin{array}{c}\text { Vpropylene, } \\
\text { ul }\end{array}$ & $\begin{array}{l}\text { polyme- } \\
\text { rization } \\
\text { tempera- } \\
\text { ture, }{ }^{\circ} \mathrm{C}\end{array}$ & $\begin{array}{c}\text { quench } \\
\text { value, } \\
\text { psi }\end{array}$ & $\begin{array}{l}\text { polyme- } \\
\text { rization } \\
\text { time } \\
s\end{array}$ & $\begin{array}{l}\text { polymer } \\
\text { yield, } \\
g\end{array}$ & $\begin{array}{c}\text { activity, } \\
\text { gPp } \times(\text { mmol } \mathrm{Zr} \times \\
\times \mathrm{h})^{-1}\end{array}$ \\
\hline rac-13 & 0.08 & 500 & isohexane & 4098 & 1000 & 70 & 20 & 223 & 0.2794 & 56280 \\
\hline rac-13 & 0.08 & 500 & isohexane & 4098 & 1000 & 100 & 20 & 186 & 0.2007 & 48530 \\
\hline rac-14 & 0.08 & 500 & isohexane & 4098 & 1000 & 70 & 20 & 377 & 0.2437 & 29066 \\
\hline rac-14 & 0.08 & 500 & isohexane & 4098 & 1000 & 100 & 20 & 278 & 0.1847 & 29908 \\
\hline rac-15 & 0.08 & 500 & isohexane & 4098 & 1000 & 70 & 15 & 652 & 0.1789 & 12349 \\
\hline rac-15 & 0.08 & 500 & isohexane & 4098 & 1000 & 100 & 15 & 322 & 0.1384 & 19318 \\
\hline rac-16 & 0.08 & 500 & toluene & 4098 & 1000 & 70 & 8 & 1082 & 0.0621 & 2582 \\
\hline rac-16 & 0.08 & 500 & toluene & 4098 & 1000 & 100 & 8 & 317 & 0,0788 & 11176 \\
\hline rac-I & 0.075 & 531 & isohexane & 4098 & 1000 & 70 & 20 & 68 & 0.3681 & 260371 \\
\hline rac-I & 0.075 & 531 & isohexane & 4098 & 1000 & 100 & 20 & 56 & 0.2961 & 253813 \\
\hline
\end{tabular}

Polymer analysis. For analytical testing, polymer sample solutions were prepared by dissolving polymer in 1,2,4-trichlorobenzene (TCB, 99+\% purity from Sigma-Aldrich) containing 2,6-di-tert-butyl- 4methylphenol (BHT, 99\% from Aldrich) at $165^{\circ} \mathrm{C}$ in a shaker oven for approximately 3 hours. The typical concentration of polymer in solution was between 0.1 to $0.9 \mathrm{mg} / \mathrm{ml}$ with a BHT concentration of 1.25 $\mathrm{mg} / \mathrm{ml}$. Samples were cooled to $135^{\circ} \mathrm{C}$ for testing.

High temperature size exclusion chromatography was performed using an automated "Rapid GPC" system [14]. $M_{w}, M_{n}$, and polydispersity index (PDI $=M_{w} / M_{n}$ ) of the polymer were measured by Gel Permeation Chromatography using a Symyx Technology GPC equipped with evaporative light scattering detector and calibrated using polystyrene standards (Polymer Laboratories: Polystyrene Calibration Kit S-M-10: Mp (peak Mw) between 5000 and 3,390,000). Samples (250 uL of a polymer solution in TCB were injected into the system) were run at an eluent flow rate of $2.0 \mathrm{~mL} / \mathrm{min}\left(135{ }^{\circ} \mathrm{C}\right.$ sample temperatures, $165^{\circ} \mathrm{C}$ oven/columns) using three Polymer Laboratories PLgel $10 \mu \mathrm{m}$ Mixed-B $300 \times 7.5$ $\mathrm{mm}$ columns in series. Numerical analyses were performed using Epoch software available from Symyx Technologies. The molecular weights obtained and reported are relative to linear polystyrene standards (not corrected to polypropylene values).

Differential Scanning Calorimetry (DSC) measurements were performed on a TA-Q100 instrument to determine the melting point of the polymers. Samples were pre-annealed at $220{ }^{\circ} \mathrm{C}$ for 15 minutes and then allowed to cool to room temperature overnight. The samples were then heated to $220^{\circ} \mathrm{C}$ at a rate of $100{ }^{\circ} \mathrm{C} / \mathrm{min}$ and then cooled at a rate of $50{ }^{\circ} \mathrm{C} / \mathrm{min}$. Melting points were collected during the heating period.

Polymer samples for ${ }^{13} \mathrm{C}$ NMR spectroscopy were dissolved in 1,1,2,2-tetrachloroethane-d2 and the samples were recorded at $125^{\circ} \mathrm{C}$ using a NMR spectrometer with a ${ }^{13} \mathrm{C}$ NMR frequency of 100 or 175 $\mathrm{MHz}$. Polymer resonance peaks are referenced to $\mathrm{mmmm}=21.8 \mathrm{ppm}$. Calculations involved in the characterization of polymers by NMR follow the works [15]. 


\section{High pressure propylene polymerization experiments}

Table S2. Additional high pressure propylene polymerization data

\begin{tabular}{|c|c|c|c|c|c|c|c|}
\hline pre-catalyst & $\begin{array}{c}\mathrm{n}_{\text {pre-catalyst, }} \\
\text { umol }\end{array}$ & $\begin{array}{c}\mathrm{n}_{\mathrm{AB}}{ }^{\mathrm{a}} \\
\mathrm{umol}\end{array}$ & $\mathrm{AB} / \mathrm{Zr}^{a}$ & $\begin{array}{c}\text { TNOA, } \\
\mathrm{mmol}\end{array}$ & $\mathrm{Al} / \mathrm{Zr}$ & $\begin{array}{c}\text { Propylene } \\
\text { concentration, M }\end{array}$ & PP yield, g \\
\hline rac-15-Me & 0.190 & 0.23 & 1.2 & 0.029 & 151 & $\sim 3.55$ & 0.829 \\
\hline rac-I-Me & 0.125 & 0.15 & 1.2 & 0.029 & 229 & $\sim 3.55$ & 1.210 \\
\hline rac-II-Me & 0.210 & 0.25 & 1.2 & 0.029 & 137 & $\sim 3.55$ & 0.986 \\
\hline
\end{tabular}

a $\left[\mathrm{HMe}_{2} \mathrm{NPh}\right]^{+}\left[\mathrm{B}\left(\mathrm{C}_{6} \mathrm{~F}_{5}\right)_{4}\right]^{-;} ;{ }^{b}$ tri-n-octylaluminum

Polymer analysis. Gel permeation chromatography was performed using a Waters 2000 Gel Permeation Chromatograph equipped with DRI detector and three columns in series (Polymer Laboratories Mixed Bed Type "LS" "B", $10 \mu \mathrm{m}, 300 \times 7.8 \mathrm{~mm}$ ). Injector, detector and column temperatures were $135{ }^{\circ} \mathrm{C}$. The eluent was inhibited TCB $(1500 \mathrm{ppm}$ of $\mathrm{BHT})$; the eluent flow was $0.5 \mathrm{ml} / \mathrm{min}$. Standards and samples were prepared in inhibited TCB (1500 ppm of BHT) at $\sim 0.75 \mathrm{mg} / \mathrm{ml}$ concentration, placed on a PL Labs 260 Heater/Shaker at $160{ }^{\circ} 30 \mathrm{C}$ for two hours, filtered through a 0.45 micron steel filter cup, and then analyzed. The injection volume was 301.5 ul. Polymer Laboratories EasiCal Preprepared Polymer calibrants were used for calibrating the GPC. The polypropylene molecular weights were calculated based on polystyrene molecular weights using the Mark-Houwink equation and constants, for polypropylene: alpha $=0.670, \mathrm{~K}=1.750 \cdot 10^{-4}$; for polystyrene: alpha $=$ $0.705, \mathrm{~K}=2.288 \cdot 10^{-4}$.

Thermal transitions were measured on heating and cooling the sample from the solid state and melt respectively using Differential Scanning Calorimetry (DSC). For crystallization temperature $\left(T_{c}\right)$ and melting temperature $\left(T_{m}\right)$, the measurements were conducted using a TA Instrument MDSC 2920 or Q1000 Tzero-DSC and data analyzed using the standard analysis software by the vendor. 3 to $10 \mathrm{mg}$ of polymer was encapsulated in an aluminum pan and loaded into the instrument at room temperature. The sample was heated to $210^{\circ} \mathrm{C}$, cooled to $-70{ }^{\circ} \mathrm{C}$, then heated to $210^{\circ} \mathrm{C}$ all at a rate of $10^{\circ} \mathrm{C} / \mathrm{min}$. Each sample was held at $210^{\circ} \mathrm{C}$ for 5 minutes to establish a common thermal history. Crystallization behavior was evaluated by cooling the sample from the melt to subambient temperature at a cooling rate of 10 ${ }^{\circ} \mathrm{C} / \mathrm{min}$. The sample was held at the low temperature for 10 minutes to fully equilibrate in the solid state and achieve a steady state. Second heating data was measured by heating this in-situ melt-crystallized sample at $10{ }^{\circ} \mathrm{C} / \mathrm{min}$. The melting temperatures reported are the peak melting temperatures from the second melt unless otherwise indicated. 


\section{X-ray crystallography data}

Crystal structure determinations. Single crystals of complexes rac-13 and rac-14 the X-ray study were obtained by slow evaporation of solutions in dichloromethane. Crystals of these metallocenes include one and two molecules of incorporated dichloromethane, respectively. Crystals of meso-15, and meso16 study were obtained by low-temperature (up to $-30^{\circ} \mathrm{C}$ ) crystallization from their saturated toluene solutions. Crystals of meso-15 include 2.5 molecules of incorporated toluene per molecule of the metallocene. Crystals of meso-16 include 0.6 molecules of incorporated toluene per one crystal cell consisting of two crystallographically independent molecules of the metallocene.

X-ray experiments were carried out using SMART 1000 CCD diffractometer $(\lambda($ Mo-K $\alpha)=0.71073 \AA$, graphite monochromator, $\omega$-scans) at $110 \mathrm{~K}$. All structures were solved by the direct methods and refined by the full-matrix least-squares procedure in anisotropic approximation for non-hydrogen atoms. All the hydrogen atoms were placed in geometrically calculated positions and included in the refiniment using riding approximation. The details of data collection and crystal structures refinement for which we used SAINT Plus[16], SADABS[17] and SHELXTL-97[18] program packages, are summarized in Tables S3 through S6. Crystallographic data for rac-13, rac-14, meso-15, and meso-16 have been deposited with the Cambridge Crystallographic Data Center, CCDC Nos. 1409566, 1409567, 1409565, 1919452, respectively. Copies of this information may be obtained from the Director, CCDC, 12 Union Road, Cambridge CB2 1EZ, UK (Fax: +44 1223 336033; e-mail: deposit@ccdc.cam.ac.uk or www.ccdc.cam.ac.uk). 
Table S3. Crystal data and structure refinement for rac-13.

Identification code

Empirical formula

Formula weight

Temperature

Wavelength

Crystal system, space group

Unit cell dimensions

Volume

Z, Calculated density

Absorption coefficient

$\mathrm{F}(000)$

Crystal size

Theta range for data collection

Limiting indices

Reflections collected / unique

Absorption correction

Max. and min. transmission

Refinement method

Data / restraints / parameters

Goodness-of-fit on $\mathrm{F}^{\wedge} 2$

Final $R$ indices [l>2sigma(I)]

$R$ indices (all data)

Largest diff. peak and hole rac-13

$\mathrm{C}_{31} \mathrm{H}_{30} \mathrm{Cl}_{4} \mathrm{~N}_{2} \mathrm{SiZr}$

691.68

110(2) K

$0.71073 \mathrm{~A}$

Triclinic, P-1

$a=9.4325(15) \AA \quad \alpha=92.631(3)^{\circ}$

$\mathrm{b}=11.887(2) \AA \quad \beta=96.166(3)^{\circ}$

$c=13.786(2) \AA \quad \gamma=107.165(3)^{\circ}$

1463.5(4) $\AA^{3}$

2, $1.570 \mathrm{Mg} / \mathrm{m}^{3}$

$0.807 \mathrm{~mm}^{-1}$

704

$0.1 \times 0.4 \times 0.6 \mathrm{~mm}$

1.80 to $30.01^{\circ}$

$-13 \leq \mathrm{h} \leq 13,-16 \leq \mathrm{k} \leq 16,-19 \leq \mathrm{I} \leq 19$

$17350 / 8413[R$ (int) $=0.0267]$

Semi-empirical from equivalents

0.862199 and 0.421941

Full-matrix least-squares on $\mathrm{F}^{\wedge} 2$

8411 / 0 / 472

1.083

$\mathrm{R} 1=0.0509, \mathrm{wR} 2=0.1348$

$\mathrm{R} 1=0.0565, \mathrm{wR} 2=0.1404$

3.892 and -0.866 e. $\AA^{3}$ 
Table S4. Crystal data and structure refinement for rac-14.

Identification code

Empirical formula

Formula weight

Temperature

Wavelength

Crystal system

Space group

Unit cell dimensions

Volume

Z

Density (calculated)

Absorption coefficient

$F(000)$

Crystal size

Theta range for data collection

Index ranges

Reflections collected

Independent reflections

Completeness to theta $=29.00^{\circ}$

Absorption correction

Max. and min. transmission

Refinement method

Data / restraints / parameters

Goodness-of-fit on $\mathrm{F}^{2}$

Final $R$ indices [l>2sigma(I)]

$R$ indices (all data)

Largest diff. peak and hole rac-14

$\mathrm{C}_{38} \mathrm{H}_{32} \mathrm{Cl}_{2} \mathrm{~N}_{2} \mathrm{SiZr} \cdot 2\left(\mathrm{CH}_{2} \mathrm{Cl}_{2}\right)$

876.72

110(2) K

$0.71073 \AA$

Triclinic

P-1

$a=11.796(2) \AA$

$\alpha=106.085(5)^{\circ}$.

$\mathrm{b}=13.167(2) \AA$

$\beta=107.590(5)^{\circ}$.

$c=13.660(3) \AA$

$\gamma=95.736(6)^{\circ}$.

1903.8(6) $\AA^{3}$

2

$1.529 \mathrm{Mg} / \mathrm{m}^{3}$

$0.774 \mathrm{~mm}^{-1}$

892

$0.05 \times 0.2 \times 0.2 \mathrm{~mm}^{3}$

1.64 to $29.00^{\circ}$.

$-16 \leq \mathrm{h} \leq 16,-17 \leq \mathrm{k} \leq 17,-18 \leq \mathrm{I} \leq 18$

21159

$10060[R$ (int) $=0.0717]$

$99.5 \%$

Semi-empirical from equivalents

0.9281 and 0.6034

Full-matrix least-squares on $\mathrm{F}^{2}$

10060 / 0 / 451

0.824

$\mathrm{R} 1=0.0592, \mathrm{wR} 2=0.1264$

$\mathrm{R} 1=0.1155, \mathrm{wR} 2=0.1417$

1.293 and -0.532 e. $\AA^{-3}$ 
Table S5. Crystal data and structure refinement for meso-15.

Identification code

Empirical formula

Formula weight

Temperature

Wavelength

Crystal system, space group

Unit cell dimensions

Volume

$Z$, Calculated density

Absorption coefficient

$F(000)$

Crystal size

Theta range for data collection

Limiting indices

Reflections collected / unique

Completeness to theta $=26.02$

Absorption correction

Max. and min. transmission

Refinement method

Data / restraints / parameters

Goodness-of-fit on $\mathrm{F}^{\wedge} 2$ meso-15

$\mathrm{C}_{63.50} \mathrm{H}_{55} \mathrm{Cl}_{2} \mathrm{~N}_{2} \mathrm{SiZr}$

1036.31

120(2) K

$0.71073 \AA$

Monoclinic, $\mathrm{P}$

$a=17.785(6) \AA \quad \alpha=90^{\circ}$

$\mathrm{b}=17.145(6) \AA \quad \beta=96.565(7)^{\circ}$

$c=17.805(6) \AA \quad \gamma=90^{\circ}$

5394(3) $\AA^{3}$

4, $1.276 \mathrm{Mg} / \mathrm{m}^{3}$

$0.366 \mathrm{~mm}^{-1}$

2152

$0.2 \times 0.2 \times 0.2 \mathrm{~mm}$

2.09 to $26.02^{\circ}$

$-21 \leq \mathrm{h} \leq 21,-21 \leq \mathrm{k} \leq 13,-14 \leq \mathrm{I} \leq 21$

$28057 / 10260[R($ int $)=0.0615]$

$96.6 \%$

None

0.928 and 0.656

Full-matrix least-squares on $\mathrm{F}^{2}$

10260 / 0 / 643

0.992

Final $R$ indices [for 5920 refl. with $\mathrm{I}>2$ sigma $(\mathrm{I})$ ] $\mathrm{R} 1=0.0656$, wR2 $=0.1452$

$R$ indices (all data)

$\mathrm{R} 1=0.1161, \mathrm{wR} 2=0.1615$

Largest diff. peak and hole

1.182 and -0.602 e. $\AA^{3}$ 
Table S6. Crystal data and structure refinement for meso-16.

Identification code

Empirical formula

Formula weight

Temperature

Wavelength

Crystal system

Space group

Unit cell dimensions

Volume

Z

Density (calculated)

Absorption coefficient

$F(000)$

Crystal size

Theta range for data collection

Index ranges

Reflections collected

Independent reflections

Completeness to theta $=30.53^{\circ}$

Absorption correction

Max. and min. transmission

Refinement method

Data / restraints / parameters

Goodness-of-fit on $\mathrm{F}^{2}$

Final $R$ indices [l>2sigma(I)]

$\mathrm{R}$ indices (all data)

Largest diff. peak and hole meso-16

$\mathrm{C}_{48.10} \mathrm{H}_{38.40} \mathrm{Cl}_{2} \mathrm{P}_{2} \mathrm{SiZr}$

868.54

100(2) K

$0.71073 \AA$

Triclinic

$\mathrm{P}-1$

$\mathrm{a}=15.5725(8) \AA \quad \alpha=72.7950(10)^{\circ}$

$\mathrm{b}=16.9762(9) \AA \quad \beta=89.6430(10)^{\circ}$

$\mathrm{C}=17.1840(9) \AA \quad \gamma=67.4320(10)^{\circ}$

3977.5(4) $\AA^{3}$

4

$1.450 \mathrm{Mg} / \mathrm{m}^{3}$

$0.556 \mathrm{~mm}^{-1}$

1780

$0.33 \times 0.27 \times 0.23 \mathrm{~mm}^{3}$

1.43 to $30.53^{\circ}$.

$-22 \leq \mathrm{h} \leq 22,-24 \leq \mathrm{k} \leq 24,-24 \leq \mathrm{I} \leq 24$

53109

$24248[R$ (int) $=0.0242]$

$99.6 \%$

Semi-empirical from equivalents

0.883 and 0.838

Full-matrix least-squares on $\mathrm{F}^{2}$

24248 / 0 / 981

1.013

$\mathrm{R} 1=0.0379, \mathrm{wR} 2=0.0892$

$\mathrm{R} 1=0.0588, w R 2=0.1010$

0.843 and -0.771 e. $\AA^{-3}$ 


\section{References}

[1] On P-arylation of dialkyl- and diarylphosphines see e.g: a) Hillhouse, J. H. U. S. Pat. US5550295, 1996; b) Laue, S.; Greiner, L.; Woltinger, J.; Liese, A. Continuous Application of Chemzymes in a Membrane Reactor: Asymmetric Transfer Hydrogenation of Acetophenone. Adv. Synth. Catal. 2001, 343, 711-720.

[2] On P-arylation of trimethylsilylphopshines see e.g: Tunney, S. E.; Stille, J. K. Palladium-catalyzed Coupling of Aryl Halides with (Trimethylstannyl)diphenylphosphine and (Trimethylsilyl)diphenylphosphine J. Org. Chem. 1987, 52, 748-753.

[3] Izmer, V. V.; Lebedev, A. Y.; Nikulin, M. V.; Ryabov, A. N.; Asachenko, A. F.; Lygin, A. V.; Sorokin, D. A.; Voskoboynikov, A. Z. Palladium-Catalyzed Pathways to Aryl-Substituted Indenes: Efficient Synthesis of Ligands and the Respective ansa-Zirconocenes. Organometallics 2006, 25, 12171229.

[4] Teunissen, H. T.; Hansen, C. B.; Bickelhaupt, F. A simple one pot synthesis of 1-chlorophospholes. Phosphorus, Sulfur and Silicon 1996, 118, 309-312.

[5] Gaussian 16, Revision A.03, Frisch, M. J.; Trucks, G. W.; Schlegel, H. B.; Scuseria, G. E.; Robb, M. A.; Cheeseman, J. R.; Scalmani, G.; Barone, V.; Petersson, G. A.; Nakatsuji, H.; Li, X.; Caricato, M.; Marenich, A. V.; Bloino, J.; Janesko, B. G.; Gomperts, R.; Mennucci, B.; Hratchian, H. P.; Ortiz, J. V.; Izmaylov, A. F.; Sonnenberg, J. L.; Williams-Young, D.; Ding, F.; Lipparini, F.; Egidi, F.; Goings, J.; Peng, B.; Petrone, A.; Henderson, T.; Ranasinghe, D.; Zakrzewski, V. G.; Gao, J.; Rega, N.; Zheng, G.; Liang, W.; Hada, M.; Ehara, M.; Toyota, K.; Fukuda, R.; Hasegawa, J.; Ishida, M.; Nakajima, T.; Honda, Y.; Kitao, O.; Nakai, H.; Vreven, T.; Throssell, K.; Montgomery, J. A., Jr.; Peralta, J. E.; Ogliaro, F.; Bearpark, M. J.; Heyd, J. J.; Brothers, E. N.; Kudin, K. N.; Staroverov, V. N.; Keith, T. A.; Kobayashi, R.; Normand, J.; Raghavachari, K.; Rendell, A. P.; Burant, J. C.; lyengar, S. S.; Tomasi, J.; Cossi, M.; Millam, J. M.; Klene, M.; Adamo, C.; Cammi, R.; Ochterski, J. W.; Martin, R. L.; Morokuma, K.; Farkas, O.; Foresman, J. B.; Fox, D. J. Gaussian, Inc., Wallingford CT, 2016.

[6] Tao, J. M.; Perdew, J. P.; Staroverov, V. N.; Scuseria, G. E. Climbing the Density Functional Ladder: Nonempirical Meta-Generalized Gradient Approximation Designed for Molecules and Solids. Phys. Rev. Lett. 2003, 91, 146401.

[7] Wadt, W. R.; Hay, P. J. Ab initio effective core potentials for molecular calculations. Potentials for the transition metal atoms Sc to Hg. J. Chem. Phys., 1985, 82, 270.

[8] a) Balabanov, N. B.; Peterson, K. A. Systematically convergent basis sets for transition metals. I. All-electron correlation consistent basis sets for the 3d elements Sc-Zn. J. Chem. Phys. 2005, 123, 064107.

[9] Schuchardt, K. L.; Didier, B. T.; Elsethagen, T.; Sun, L.; Gurumoorthi, V. J. Chase, J. Li, Windus T. L. Basis Set Exchange: A Community Database for Computational Sciences. J. Chem. Inf. Model. 2007, 47, 1045.

[10] Balabanov, N. B.; Peterson, K. A. Basis set limit electronic excitation energies, ionization potentials, and electron affinities for the $3 d$ transition metal atoms: Coupled cluster and multireference methods. J. Chem. Phys. 2006, 125, 074110.

[11] Schuchardt, K. L.; Didier, B. T.; Elsethagen, T.; Sun, L.; Gurumoorthi, V.; Chase, J.; Li, J.; Windus, T. L. Basis Set Exchange: A Community Database for Computational Sciences. J. Chem. Inf. Model. 2007, 47, 1045. 
[12] Ehm, C.; Budzelaar, P. H. M.; Busico, V. Calculating accurate barriers for olefin insertion and related reactions. J. Organomet. Chem. 2015, 775, 39.

[13] Manz, T.A.; Limasa, N.G. Introducing DDEC6 atomic population analysis: part 1. Charge partitioning theory and methodology. RSC Adv. 2016, 6, 47771.

[14] Petro, M. U.S. Pat. US6491816, 2002.

[15] a) Bovey F. A. in "Polymer Conformation and Configuration" Academic Press, New York, 1969;

b) Randall J. in "Polymer Sequence Determination, Carbon-13 NMR Method", Academic Press, New York, 1977.

[16] SMART and SAINT, Release 5.0, Area Detector control and Integration Software, Bruker AXS, Analytical X-Ray Instruments, Madison, Wisconsin, USA, 1998.

[17] Sheldrick, G.M. SADABS: A Program for Exploiting the Redundancy of Area-detector X-Ray Data, University of Göttingen, Göttingen, Germany, 1999.

[18] Sheldrick, G.M. SHELXTL-97 Program for Solution and Refinement of Crystal Structure, Bruker AXS Inc., Madison, WI-53719, USA, 1997. 